\title{
Effect of Compression Ratio on Energy and Emission Performance of Single Cylinder Diesel Engine Fueled with Jatropha and Karanja Biodiesel
}

\author{
Ekanath R. Deore ${ }^{1 *}$, Ramchandra S. Jahagirdar ${ }^{1}$ \\ Department of Mechanical Engineering, J. J. T. University, Chudela, Rajasthan State, Pin, India \\ E-mail: ${ }^{1}$ erdmech@yahoo.com,j_ramchandra@yahoo.com
}

\begin{abstract}
Over the last 10 years biodiesel fuel has been studied extensively as an alternative fuel. Most of the researchers reported the performance and emissions of biodiesel and their blends with a constant compression ratio. Also all the research was conducted with the use of a single biodiesel and its blend. Few reports are observed with the use of variable compression ratio. The main aim of the present study is to analyze the performance and emission of two biodiesels for various compression ratios and explore the use of more than one blend of biodiesel with diesel. In the present study Jatropha and Karanja biodiesel was tested in a single cylinder VCR DI diesel engine for three compression ratio 14, 16 and 18. A longer delay period was observed for Jatropha fuel compared with Karanja fuel, which is the main reason for the low $\mathrm{NO}_{\mathrm{x}}$ emissions with Karanja Fuel.
\end{abstract}

Keywords: Biodiesel; compression ratio; emission.

\section{Introduction}

Biodiesel fuels are derived from vegetable oils, animal fats and used waste cooking oil. It can be used in its neat form or can be blended with petroleum based diesel fuel. Biodiesel is renewable, environment friendly and can be available as a crop in most rural areas (Harrington, 1986; Kloptenstem, 1988; Lepori, 1992; Masjuki, 1993; Srinivasa, 1991). Vegetable oils are produced from plants and hence their burning gases do not have any sulphur content (Stavarache, 2005). Many researchers reported that engine power is reduced (Aydin, 2010; Carraretto, 2004; Hansen, 2006; Hazar, 2009; Karabektas, 2009; Murillo, 2007; Ozsezen, 2009; Raheman, 2004 Reyes, 2006) due to the fact that blending of biodiesel reduces the heating value compared with petroleum based diesel. Some authors found that the addition of biodiesel initially increases the power output, reaches a maximum value and then decreases (AlWidyan, 2002; DaSilva, 2003; Gumus, 2010; Monyem, 2001; Oner, 2009; Song, 2008).

Some literature explains that the power of the engine is recovered due to the high viscosity of biodiesel. High viscosity improves the air fuel ratio because of fuel spray penetration during injection (Lin, 2009; Oner, 2009). Most researchers (Aydin, 2010; Hansen, 2006; Karabeketas, 2009; Murillo, 2007; Ozsezen, 2009 ) reported that fuel consumption of an engine increases.

The increasing fuel consumption is due to the reduction in the heating value of biodiesel blends. Due to lower heating value of B100 biodiesel, brake specific fuel consumption (BSFC) increased by 12\% (Armas, 2009; Hasimoglua, 2008). With increasing content of Karanja biodiesel, fuel consumption increases (Godiganur, 2010; Raheman, 2004). For B100 Karanja biodiesel, BSFC increased by $13.31 \%$ (Sahoo et. al., 2009).

Particle Matter (PM) emission reduced with the use of biodiesel. PM was reduced $40 \%$ compare with biodiesel (DaSilva, 2003; Gumus, 2010; Hasimoglua, 2008). It is observed that PM reduced by $68.83 \%$ for B100 Karanja biodiesel and $64.28 \%$ for B100 Jatropha biodiesel (Sahoo et. al., 2009). Literatures reported that $\mathrm{NO}_{\mathrm{x}}$ emission increased with the increase in content of biodiesel. $\mathrm{NO}_{\mathrm{x}}$ emission increased by $44.8 \%$ for B 100 biodiesel (Lujan et. al., 2009). A comparative study was conducted for Karanja and Jatropha biodiesel. For Karanja biodiesel $\mathrm{NO}_{\mathrm{x}}$ emission increased with increase in content and for Jatropa biodiesel there is variation in $\mathrm{NO}_{\mathrm{x}}$ emission (Sahoo et. al., 2009). Most of the literatures reported that with the use of pure biodiesel $\mathrm{CO}$ emission reduced compared with diesel fuel (Aydin, 2010; Buyukkaya, 2010; Carraretto, 2004; Choi, 2006; Hazar, 2009; Ozsezen, 2009; Raheman, 2004; Ulusoy, 2004; ). CO emission was reduced by $74-94 \%$ for B100 Karanja biodiesel (Raheman \& Phadtare, 2004). CO emission was increased for Jatropha biodiesel and reduced for Karanja biodiesel (Sahoo et. al., 2009). Many authors reported that hydrocarbon (HC) emission decreases with increases in content of biodiesel (Ghobadian, 2009; Godiganur, 2010; Kim, 2010; Mahanta, 2006).

All these literatures findings are based on a single fix compression ratio and use of a single biodiesel fuel. Compression ratio has a significant effect on the combustion and emission of the engine. Few literatures were observed with findings of varied compression ratio. Hence the aim of this work is to identify the performance of two biodiesels (Jatropha and Karanja) at three different compression ratios 14,16 and 18 and to explore the possibility of use of blends of more than one biodiesel

\section{Materials and Method}

A locally obtained commercial diesel fuel was used as a base line fuel for this study. Test fuel samples are prepared at the Shri Shivaji Vidya Prasarak Sanstha's (SSVPS) College of Engineering.

A few properties are tested from the third party, Horizon Services Chemical Lab at Pune (Maharashtra) and other properties are tested in a college laboratory. Table 1 represents properties of test fuels. D is referred as pure diesel, $\mathrm{K}$ is for Karanja fuel, and $\mathrm{J}$ is for Jatropha fuel. JB is for Jatropha biodiesel blend and KB is for Karanja biodiesel blend. Engine oil used for the study purpose meets the API CH-4, ACEA A3/B4, SAE 15W-40 specification. 
Table 1. Properties of Test Fuels.

\begin{tabular}{l|lllllll|}
\hline $\begin{array}{l}\text { Sr. } \\
\text { No. }\end{array}$ & $\begin{array}{l}\text { Fuel } \\
\text { Blend }\end{array}$ & $\begin{array}{l}\text { Density } \\
\left(\mathbf{k g} / \boldsymbol{m}^{\mathbf{3}}\right)\end{array}$ & $\begin{array}{l}\boldsymbol{C V} \\
(\boldsymbol{k J} / \mathbf{k g})\end{array}$ & $\begin{array}{l}\text { Viscosity } \\
(\boldsymbol{c S t})\end{array}$ & $\begin{array}{l}\text { Flash Point } \\
\left({ }^{\boldsymbol{o}} \boldsymbol{C}\right)\end{array}$ & $\begin{array}{l}\text { Cloud Point } \\
\left({ }^{\boldsymbol{o}} \boldsymbol{C}\right)\end{array}$ & $\begin{array}{l}\text { Pour Point } \\
\left.\boldsymbol{(}^{\boldsymbol{o}} \boldsymbol{C}\right)\end{array}$ \\
\hline 1 & D & 828 & 42300 & 2.85 & 76 & 6.5 & 3.1 \\
2 & J & 870 & 39450 & 4.56 & 150 & 10 & 4.2 \\
3 & K & 880 & 39890 & 4.52 & 166 & 14.2 & 5.1 \\
4 & JB20 & 820 & 42050 & 3.08 & 86 & 6.6 & 3.1 \\
5 & JB40 & 840 & 41750 & 3.78 & 102 & 6.9 & 3.2 \\
6 & JB60 & 848 & 41510 & 3.92 & 122 & 7.3 & 3.3 \\
7 & JB80 & 858 & 41390 & 4.04 & 136 & 7.6 & 3.4 \\
8 & KB20 & 844 & 40690 & 3.06 & 100 & 8.6 & 3.1 \\
9 & KB40 & 848 & 40307 & 3.58 & 106 & 9.9 & 3.3 \\
10 & KB60 & 852 & 40120 & 3.92 & 128 & 11.3 & 3.6 \\
11 & KB80 & 864 & 38980 & 4.34 & 148 & 12.4 & 4.0 \\
12 & Method & ASTM D4052 & ASTM D240 & ASTM D445 & ASTM D93 & ASTM D2500 ASTM D97 \\
\hline
\end{tabular}

The test setup consists of a single cylinder, four stroke, VCR (Variable Compression Ratio) Diesel engine connected to an eddy current type dynamometer for loading. The compression ratio can be changed without stopping the engine and without altering the combustion chamber geometry by tilting the cylinder block arrangement. The setup is provided with the necessary instruments for combustion pressure and crank-angle measurements. These signals are interfaced to a computer through an engine indicator for pressure crank angle diagrams. Provisions are also made for interfacing airflow, fuel flow, temperatures and load measurements. The setup has a stand-alone panel box consisting of an air box, two fuel tanks for duel fuel tests, manometer, fuel measuring unit, transmitters for air and fuel flow measurements, process indicator and engine indicator. Rotameters are provided for cooling water and calorimeter water flow measurement. The setup enables the study of VCR engine performance for brake power, indicated power, frictional power, BMEP, IMEP, brake thermal efficiency, indicated thermal efficiency, mechanical efficiency, volumetric efficiency, specific fuel consumption, $\mathrm{A} / \mathrm{F}$ ratio, and heat balance. The Labview based Engine Performance Analysis software package "EnginesoftLV" is used for on line performance evaluation. This software provides the data regarding pressure versus crank angle, mass fraction burn, net heat release rate, etc. A computerized Diesel injection pressure measurement is optionally provided. Table 2 represents the engine specifications and Figure1 shows a photograph of the test setup.

Emission analysis was conducted with a portable emission analyzer DELTA 1600S. Exhaust gases from the engine were taken directly to the sampling tube. It measures carbon monoxide (CO), carbon dioxide $\left(\mathrm{CO}_{2}\right)$, hydrocarbons (HC) and nitric oxide (NO). Both heated line and conditioning lines are provided with the instrument. Heated line serves to avoid condensation by ensuring the gas temperature remains at about $200^{\circ} \mathrm{C}$ and conditioning line maintains the gas temperature below $40^{\circ} \mathrm{C}$ and the saturation level is correct. The DELTA 1600-L determines the emissions of $\mathrm{CO}$ (carbon monoxides), $\mathrm{CO} 2$ (carbon dioxides), $\mathrm{HC}$ (hydrocarbons) with means of infrared measurement and $\mathrm{O}_{2}$ (oxygen) and $\mathrm{NO}$ (nitrogen oxides) with means of electrochemical sensors. The 5-gas analysis is processed by the integrated micro-processor and described in the display. Table 3 represents specification of emission analyzer.
Table 2. Engine Specifications.

\begin{tabular}{|c|c|}
\hline Details & Specification \\
\hline Type & $\begin{array}{l}\text { Single cylinder, Four stroke, Variable } \\
\text { Compression Ratio Diesel Engine } \\
\text { (Computerized) }\end{array}$ \\
\hline Engine & $\begin{array}{l}\text { Kirloskar Make, Water cooled, } 3.5 \mathrm{~kW} \text { at } \\
1500 \mathrm{rpm} \text {, Stroke } 110 \mathrm{~mm} \text {, Bore } 87.5 \mathrm{~mm} \text {, } \\
661 \mathrm{cc} \text {, CR range } 12-18\end{array}$ \\
\hline Dynamometer & $\begin{array}{l}\text { Model ED-I, Eddy current type, Water } \\
\text { cooled Max load } 7.5 \mathrm{~kW} \text {. }\end{array}$ \\
\hline Piezo Sensor & Range 5000 PSI with low noise cable \\
\hline $\begin{array}{l}\text { Crank Angle } \\
\text { Sensor }\end{array}$ & $\begin{array}{l}\text { Resolution } 1 \text { degree, Speed } 5500 \text { rpm, with } \\
\text { TDC pulse }\end{array}$ \\
\hline $\begin{array}{l}\text { Data } \\
\text { Acquisition } \\
\text { Device }\end{array}$ & NI USB-62210, 16 Bit, $250 \mathrm{kS} / \mathrm{s}$ \\
\hline $\begin{array}{l}\text { Piezo } \\
\text { Powering } \\
\text { Unit }\end{array}$ & Make - Cuadra, Model - AX 409 \\
\hline $\begin{array}{l}\text { Digital Mili } \\
\text { Voltmeter }\end{array}$ & Range 0-200 mV, Panel Mounted \\
\hline $\begin{array}{l}\text { Temperature } \\
\text { Sensor }\end{array}$ & Type RTD, Thermocouple K Type \\
\hline $\begin{array}{l}\text { Temperature } \\
\text { Transmitter }\end{array}$ & $\begin{array}{l}\text { Type two wire, Input RTD PT-100, Range } \\
0-100^{\circ} \mathrm{C} \text {, Output } 4-20 \mathrm{~mA} \text { and Type two } \\
\text { wire, Input Thermocouple Range } 0- \\
1200^{\circ} \mathrm{C} \text {, Output } 4-20 \mathrm{~mA}\end{array}$ \\
\hline $\begin{array}{l}\text { Load } \\
\text { Indicator }\end{array}$ & Digital, Range $0-50 \mathrm{~kg}$, Supply $230 \mathrm{VAC}$ \\
\hline Load Sensor & $\begin{array}{l}\text { Load Cell, Type Strain Gauge, Range } 0- \\
50 \mathrm{~kg}\end{array}$ \\
\hline $\begin{array}{l}\text { Fuel Flow } \\
\text { Transmitter }\end{array}$ & DP Transmitter, Range $0-500 \mathrm{~mm} \mathrm{WC}$ \\
\hline $\begin{array}{l}\text { Air Flow } \\
\text { Transmitter }\end{array}$ & $\begin{array}{l}\text { Pressure Transmitter Range (-) } 250 \mathrm{~mm} \\
\text { WC }\end{array}$ \\
\hline Software & EnginesoftLV, \\
\hline Rotameter & $\begin{array}{l}\text { Engine Cooling } 40-400 \mathrm{LPH} \text {, } \\
\text { Calorimeter } 25-250 \mathrm{LPH}\end{array}$ \\
\hline Fuel Tank & $\begin{array}{l}\text { Capacity } 15 \text { Lit, with glass fuel metering } \\
\text { column }\end{array}$ \\
\hline Calorimeter & Type Pipe in Pipe \\
\hline
\end{tabular}




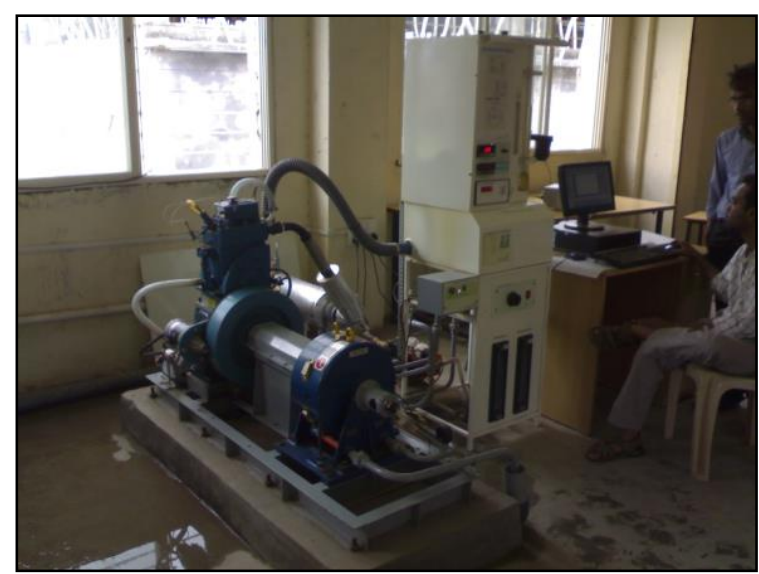

Figure 1. Photograph of Single Cylinder VCR Engine.

Table 3. Specifications of Emission Analyzer.

\begin{tabular}{l|ll}
\hline Measurement & $\begin{array}{l}\text { Measuring } \\
\text { Range }\end{array}$ & Resolution \\
\hline $\mathrm{HC}$ & $0-10000 \mathrm{ppm}$ & $1 \mathrm{ppm}$ \\
$\mathrm{CO}$ & $0.000-9.999 \%$ & $0.001 \%$ \\
$\mathrm{CO}_{2}$ & $0-20 \%$ & $0.01 \%$ \\
$\mathrm{O}_{2}$ & $0-25 \%$ & $0.01 \%$ \\
\hline
\end{tabular}

\section{Results and Discussion}

Tests were conducted on a single cylinder VCR diesel engine. All experiments were performed after ensuring a full warm-up. A plan was designed for the experimental investigation. Different blends of fuels were tested. The tests were conducted for different blends and were repeated for four times for every kind of fuel, in order to increase the reliability of the test results. For each of the fuels, the engine was run on five different loads, $2 \mathrm{~kg}, 4 \mathrm{~kg}, 6 \mathrm{~kg} 8 \mathrm{~kg}$ and $10 \mathrm{~kg}$ of break load on dynamometer. The engine load was controlled by dynamometer. The dynamometer is an eddy current type and is water cooled with a maximum load of $7.5 \mathrm{~kW}$. During the test injection timing was maintained the same for all three fuels

\subsection{Combustion Performance}

Figure 2 represents pressure versus crank angle diagram for a compression ratio of 14 . It is observed that the peak pressure of 40.97 bar was reached at an angle of 373 degree for Jatropha fuel, 39.29 bar at an angle of 375 degree for Karanja fuel and 37.35 bar at 379 degree for Diesel fuel. The pressure reached during the second stage of combustion depends on the duration of the delay period. A long delay period results in a high pressure rise, since more fuel will be present in the cylinder before the rate of burning comes under control. It was observed that the diesel fuel has a longer ignition delay than that of Jatropha and Karanja Biodiesel. For diesel fuel viscosity is high as it is a petroleum derived fuel. The high viscosity of the fuel results in longer penetration, slower mixing of fuel and poor atomization, which causes longer delay for the diesel fuel. However biodiesel is not petroleum derived as it is obtained from different feed-stocks. Due to the presence of diglycerides, the boiling point of biodiesel is higher than diesel. However during injection chemical reactions and high temperatures results in rapid gasification which causes volatile combustion and hence the delay period of biodiesel is lower than that of diesel fuel. (Sahoo et. al., 2009)

Figures 3 and 4 represent the rise in cylinder pressure for a compression ratio of 16 and 18. For a compression ratio of 16 the maximum pressure for Jatropha fuel is 47.16 bar at 370 degree, for Karanja Fuel is 45.99 bar at 372 degree and for Diesel fuel 45.89 bar at 373 degree.

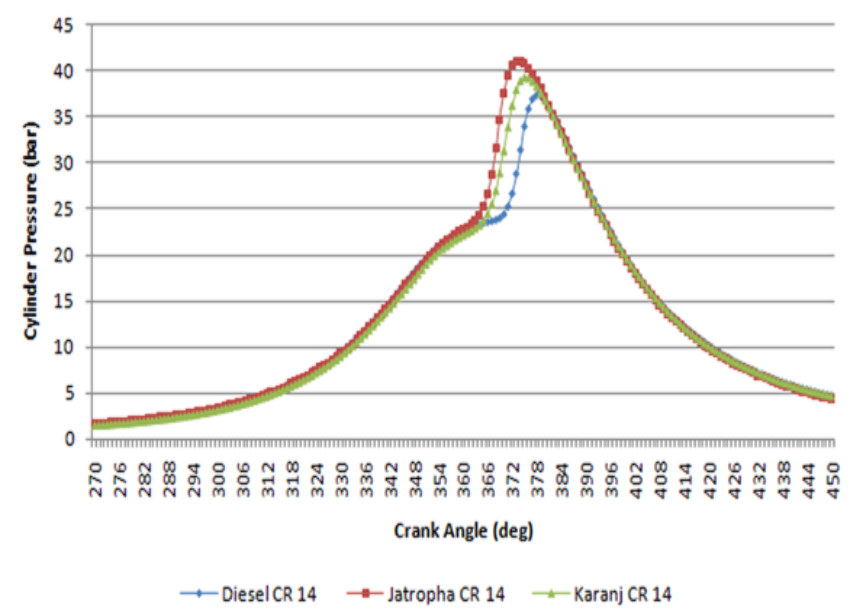

Figure 2. Pressure vs Crank Angle Diagram (CR 14).

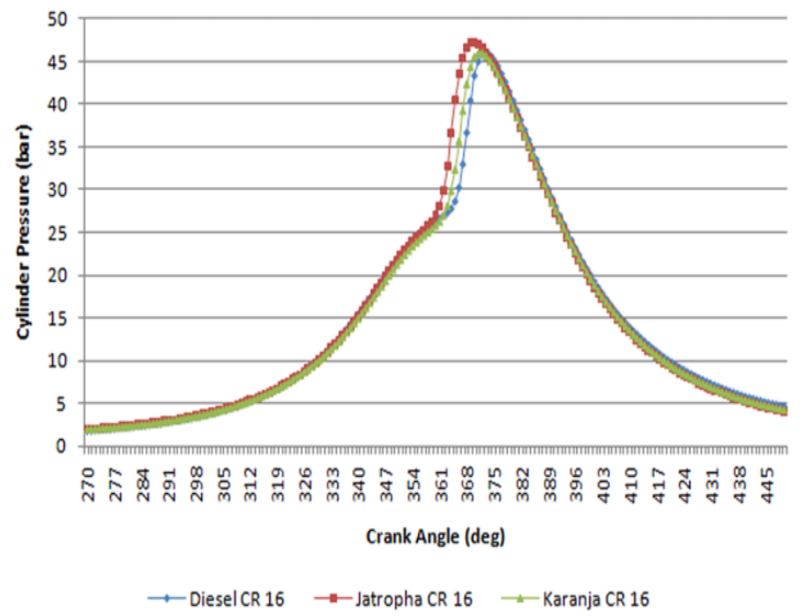

Figure 3. Pressure vs Crank Angle Diagram (CR 16).

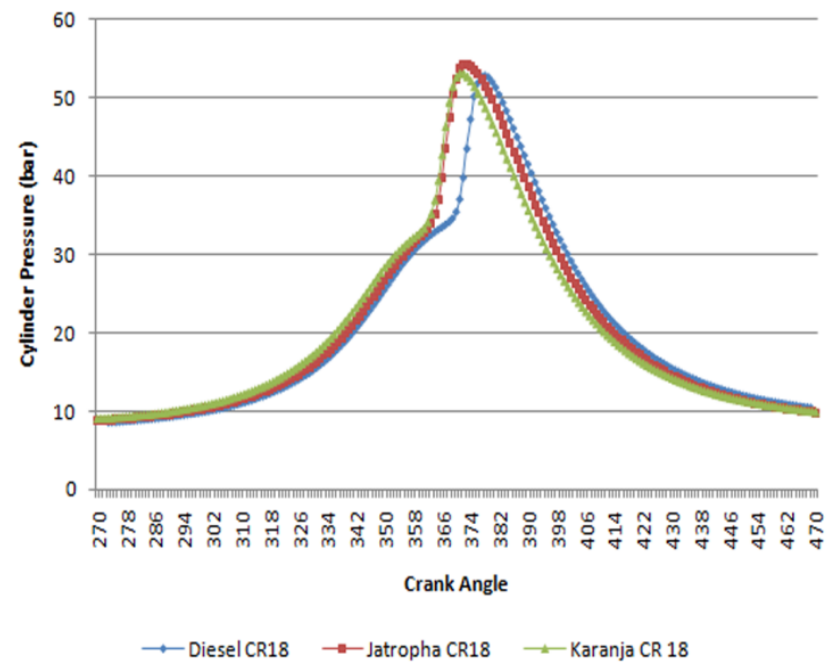

Figure 4. Pressure vs Crank Angle Diagram (CR 18).

Figure 5 represents mass fraction burn for three fuels at a compression ratio of 18 . For Jatropha and Karanja biodiesel $90 \%$ of mass fraction was burned about 18 degree after top dead center (TDC). For diesel fuel it is about 24 degree after TDC. It is observed that for Jatropha fuel $50 \%$ 
of the mass was burned at about 12 degree after TDC and for Karanja it is at about 3 degree after TDC. This indicates a longer delay period for Jatropha biodiesel compare to Kranja biodiesel. At a compression ratio $16,90 \%$ of mass fraction was burned at 16 degree after TDC for Jatropha whereas for Karanja fuel it is at 19 degree after TDC. For diesel fuel it is observed at 20 degree after TDC. It is observed that at a compression ratio of 14 both the biodiesels have same $\%$ of mass fraction burn in the engine cylinder.

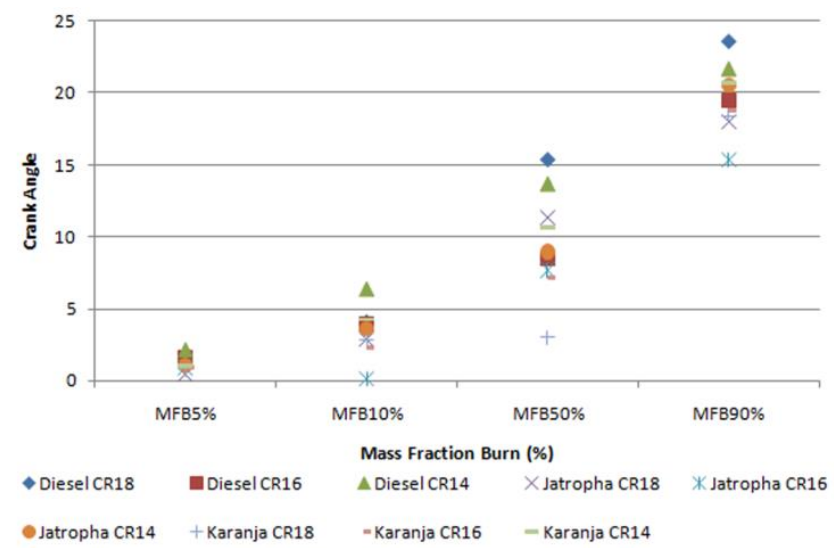

Figure 5. Mass Fraction of Fuel Burn.

Figure 6 represents net heat release for three fuels at a compression ratio $(\mathrm{CR})$ of 14,16 and 18 . It is observed that the ignition delay period for biodiesel was shorter than diesel fuel at any compression ratio. Of course it is a common observation that decreases in compression ratio increases the ignition delay for both diesel and biodiesel. Maximum heat release for the diesel fuel is more than biodiesel at any compression ratio except at a CR of 14 . Maximum heat release rate for diesel fuel is $51.56 \mathrm{~J} / \mathrm{deg}$ at CR 16 and at CR 14 it was $48.87 \mathrm{~J} / \mathrm{deg}$. High heat release rate and high peak pressure is due to the longer ignition delay for diesel fuel. For CR 18 and 16 for Jatropha fuel heat release rate was low compared with diesel and Karanja fuel. However at a very low CR of 14 Jatropha has a longer ignition delay of about $13 \mathrm{deg}$ crank angle (CA), which results in a high heat release rate and peak pressure. High peak pressure is due to a long residence of fuel in the combustion chamber. It is observed that for Karanja fuel the delay period is about $4 \mathrm{deg}$ CA more than Jatropha fuel hence peak pressure is also high.

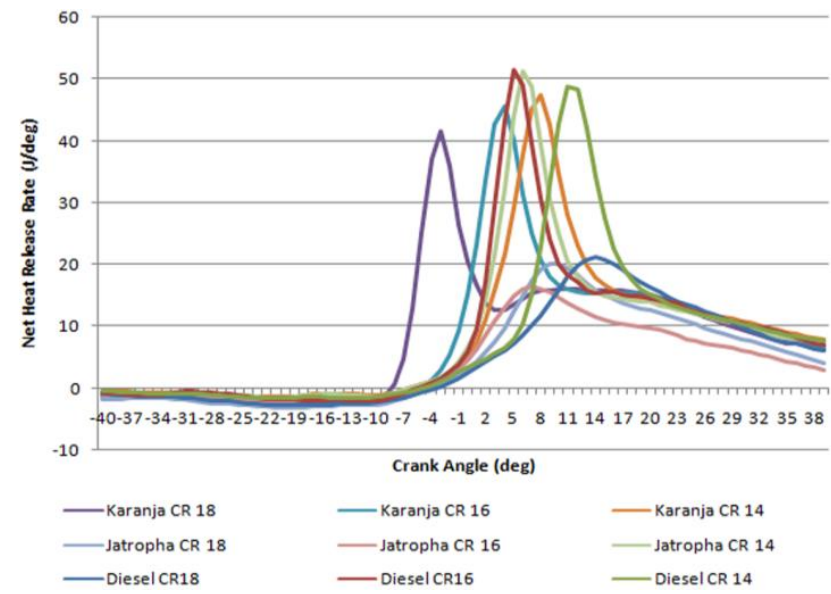

Figure 6. Cumulative Heat Release vs Crank Angle.
This shows that the blending of two biodiesel may results in low peak pressure and temperature and may result into some improvement in emission. This will be the second part of this research work.

Figure 7 represents mean gas temperature for three fuels. Karanja fuel has maximum temperature compared with the other two fuels. At a compression ratio of 18, the temperature of Karanja biodiesel is $1180^{\circ} \mathrm{C}$, Jatropha biodiesel is $830^{\circ} \mathrm{C}$ and for Diesel fuel it is $890^{\circ} \mathrm{C}$. The high temperature of Karanja and diesel fuel is observed due to the high peak pressure as a result of longer delay compared with Jatropha fuel. At compression ratio 16, Jatropha biodiesel temperature is found to be $700^{\circ} \mathrm{C}$ and no changes with temperature of Karanja biodiesel were found. However, the temperature of diesel fuel was increased to $1120^{\circ} \mathrm{C}$.

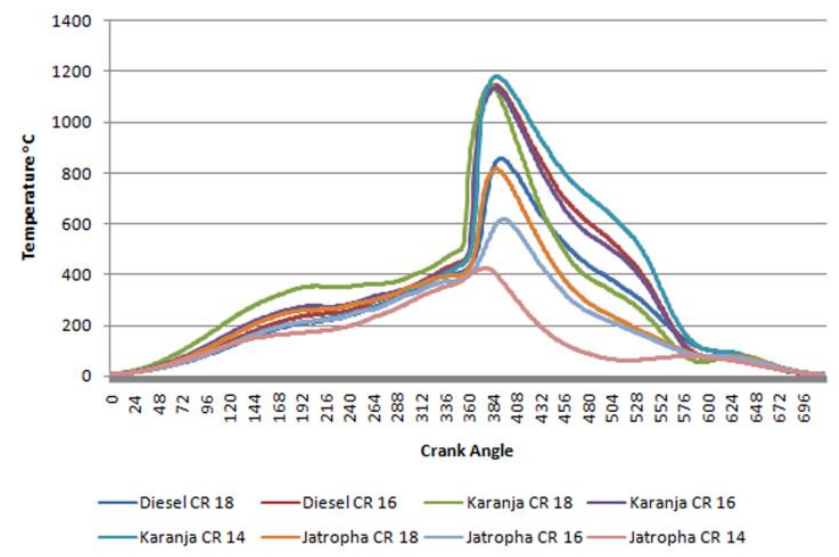

Figure 7. Mean Gas Temperature for Different Fuel.

\subsection{Energy Performance}

\subsubsection{Power Performance}

It was observed that there were no significant differences in break power of the engine between pure biodiesel (Jatropha and Karanja) and diesel fuel (Figures 8-10). At maximum load for any compression ratio the difference between petroleum diesel and pure biodiesel is less than $1 \%$ only. This is mainly due to a higher specific fuel consumption (SFC) at higher loads at any compression ratio, a lower heating value and a higher oxygen content for biodiesel. Since the density of the biodiesel fuel is more than petro diesel, biodiesel supplied to the engine is more than diesel fuel, which compensate for the loss of heating value.

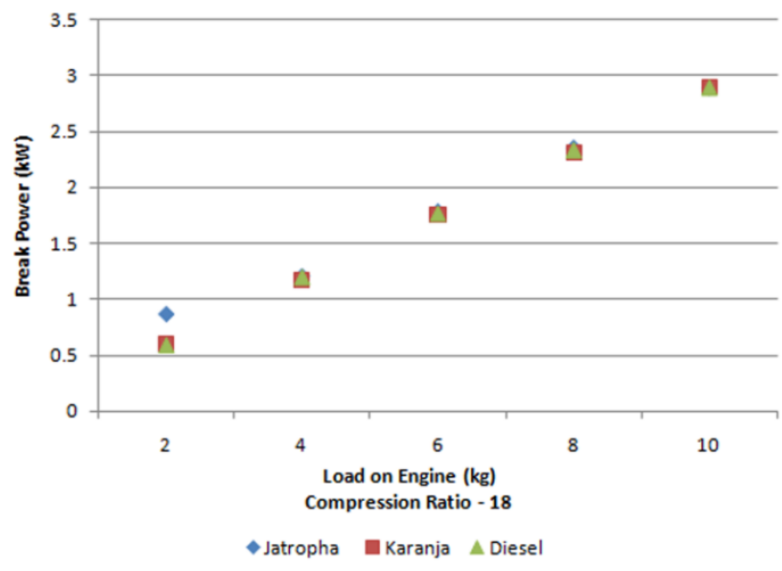

Figure 8. Effect on Brake Power of Engine CR-18. 


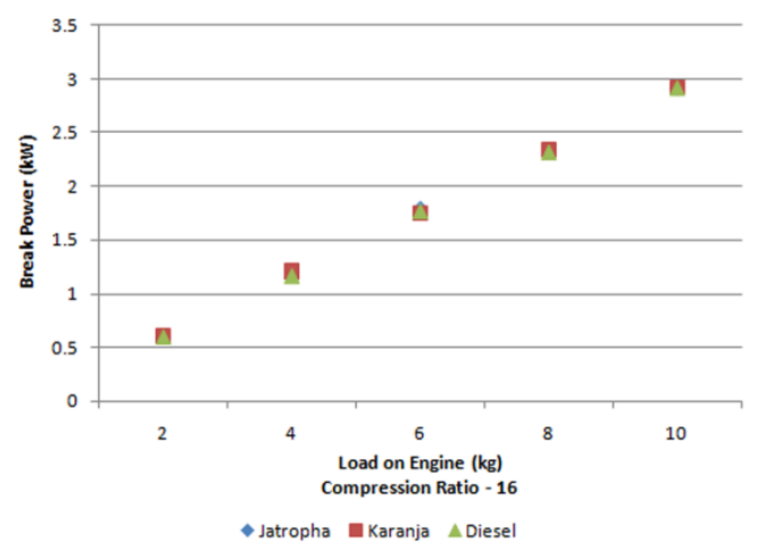

Figure 9. Effect on Brake Power of Engine CR-16.

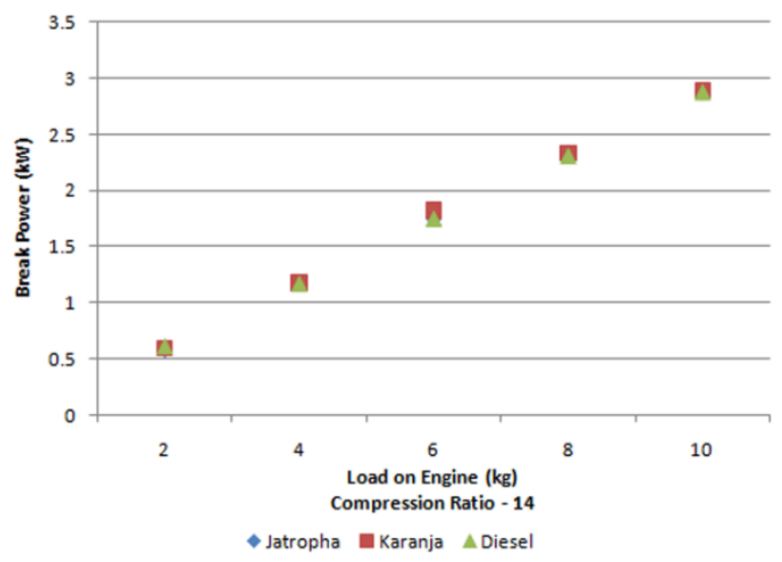

Figure 10. Effect on Brake Power of Engine CR-14.

\subsubsection{Effect on SFC and Brake Thermal Efficiency}

It was observed from Figures 11-13 SFC for Jatropha biodiesel at a CR of 18 at low load of $2 \mathrm{~kg}$ is lower than diesel fuel by $9.61 \%$ however, with an increase in load it is similar to that of diesel fuel, and higher by $3.57 \%$ at a higher load of $10 \mathrm{~kg}$. At a CR of 16 at part load operation Jatropha biodiesel has about a $6 \%$ lower SFC however, at higher loads SFC increases by about 5\%. At low CR 14 Jatropha biodiesel SFC is increased to higher side and maximum by $29 \%$ at higher load of $10 \mathrm{~kg}$. Loss of heating value of Jatropha fuel is about $9.53 \%$ and fuel consumption for Jatropha fuel is about 29\% higher at low CR 14 and higher load of $10 \mathrm{~kg}$ whereas with increase in CR to 16 fuel consumption is $6.25 \%$ higher and at a high of CR 18 is only about $3.57 \%$. At higher load fuel consumption for Jatropha is higher at any compression ratio. However at part load operation Jatropha biodiesel is found to be economical.

It was observed that at low load of 2 to $6 \mathrm{~kg}$ Karanjafuel consumption is about 11 to $30 \%$ higher compared with Jatropha biodiesel. This is mainly due to higher density and viscosity. It was observed that for Karanja biodiesel SFC is higher at any compression ratio compared with Diesel and Jatropha Biodiesel. Loss of heating value for Karanja biodiesel is $15 \%$ which is more compared with Jatropha biodiesel. For three CR's 18,16 and 14 it is observed that the SFC decreases with increase in load and at the maximum load of $10 \mathrm{~kg}$ about $10 \%$ higher fuel consumption was observed. At low load for Karanja biodiesel SFC is very high compared with Diesel fuel at a low load of $2 \mathrm{~kg}$ and about $20 \%$ higher fuel consumption is observed. Fuel consumption is higher and obviously this is because of loss of heating value and more density than that of diesel fuel.

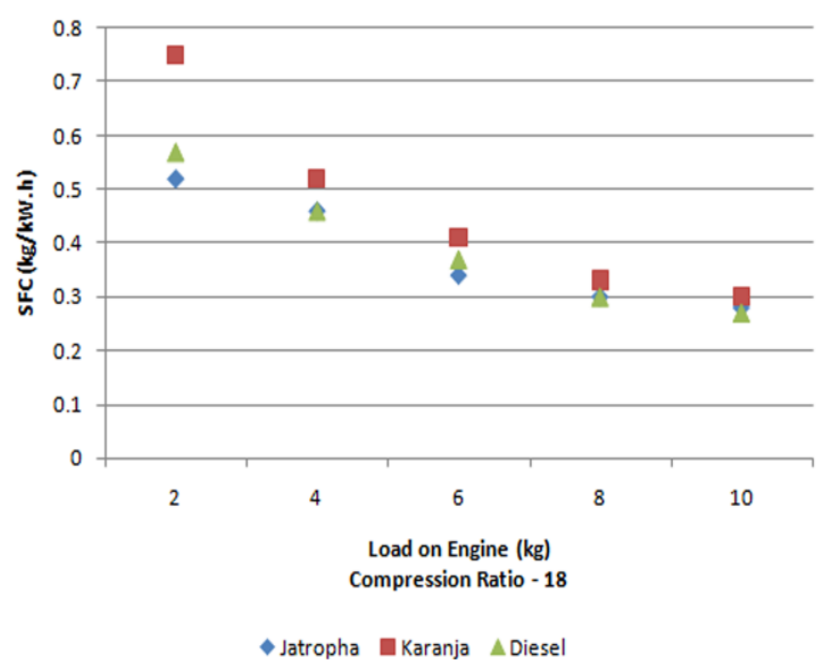

Figure 11. Effect on SFC of Engine CR-18.

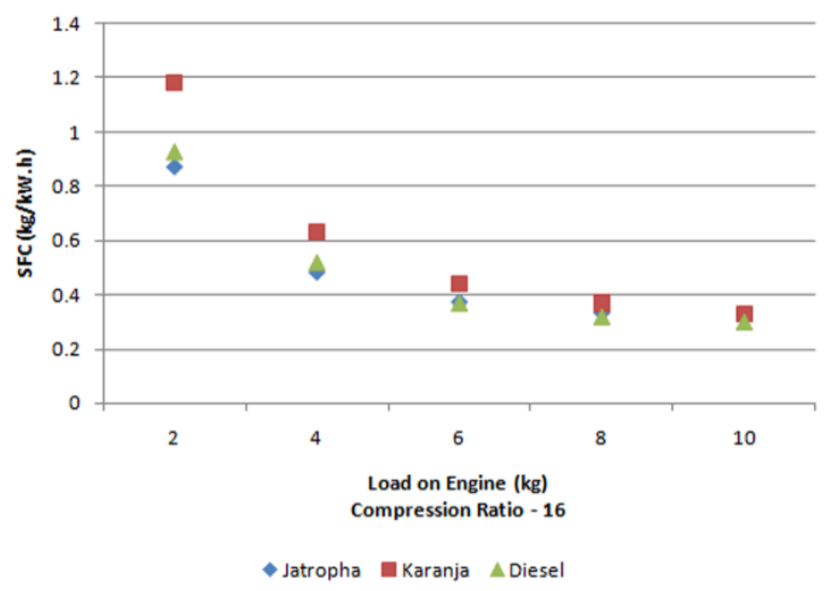

Figure 12. Effect on SFC of Engine CR-16.

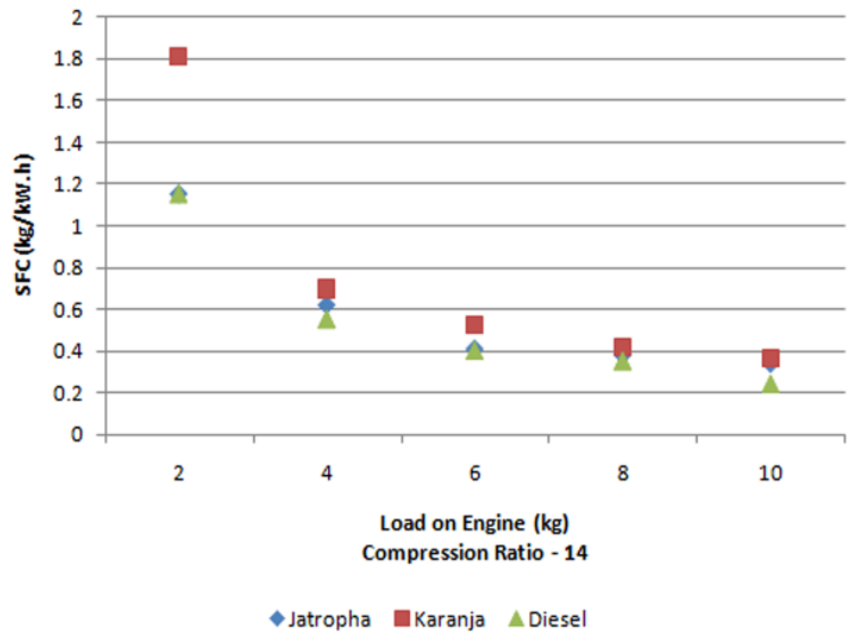

Figure 13. Effect on SFC of Engine CR-14.

Since at part load operation SFC is observed to be $6 \%$ lower than that of diesel for Jatropha fuel, break thermal efficiency is higher compared with Karanja. For CR 18 at a low load of $2 \mathrm{~kg}$ the break thermal efficiency of Jatropha fuel is about $37 \%$ higher compared with Diesel Fuel and 25.95\% higher than Karanja fuel. With increase in load on engine this deviation also reduces to a minimum. At a higher load of $10 \mathrm{~kg}$ at a compression ratio 18, Jatropha fuel has a thermal efficiency $2.76 \%$ more than Karanja and 9.29\% more than Diesel fuel (Figures 14-16). 


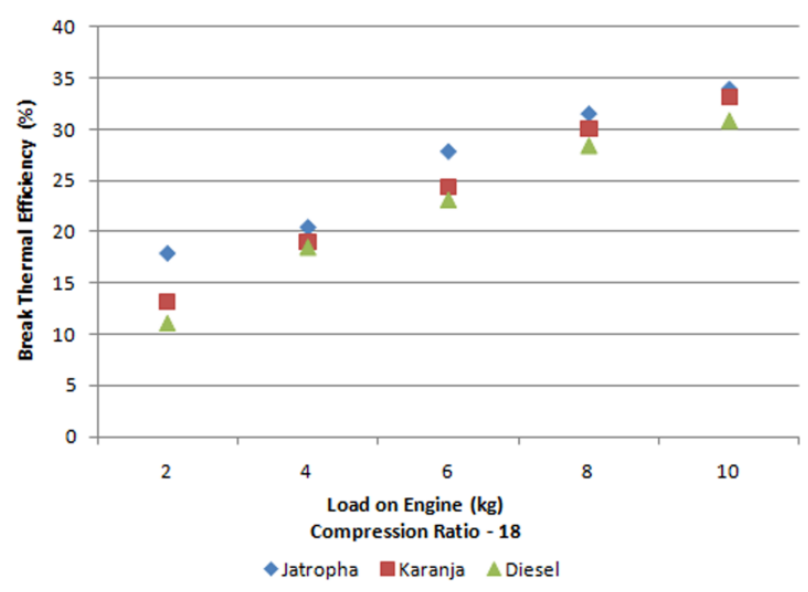

Figure 14. Effect on Brake Thermal Efficiency CR-18.

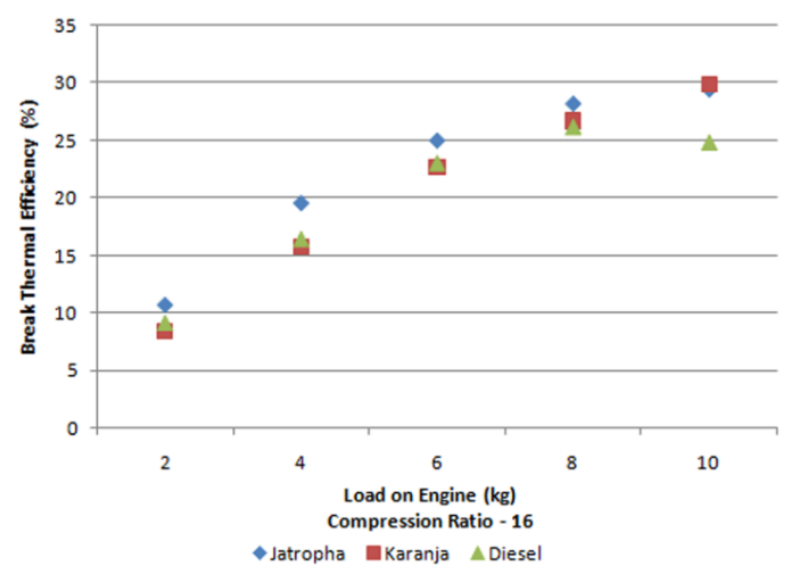

Figure 15. Effect on Brake Thermal Efficiency CR-16.

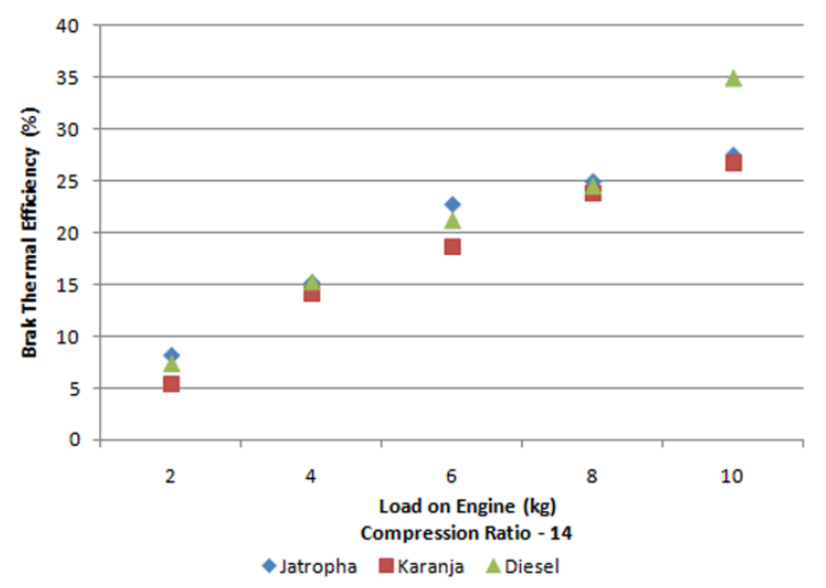

Figure 16. Effect on Brake Thermal Efficiency CR-14.

\subsubsection{Mechanical Efficiency}

It was observed that (Figures 17-19) mechanical efficiency of Jatropha fuel at CR 18 is less compared to diesel. At a full load of $10 \mathrm{~kg}$ Jatropha fuel has $8.68 \%$ less efficiency than diesel fuel. This is mainly due to high indicated power of Jatropha fuel. For Karanja fuel efficiency is $13.91 \%$ less than that of diesel fuel. However at CR 16 efficiency of Jatropha fuel is 3 to 5\% more than that of diesel and for Karanjafuel it is 4 to $8 \%$ more than that of diesel fuel for the entire range of load $(2 \mathrm{~kg}$ to $10 \mathrm{~kg})$. However, at CR 14 Jatropha fuel has efficiency similar to Diesel fuel and is observed to be higher at low load. For Karanja fuel efficiency is higher at low load about 13 to $30 \%$ high compare with diesel for load range 2 to $6 \mathrm{~kg}$. For CR 18 Jatropha fuel has efficiency is 1 to $4.5 \%$ more than

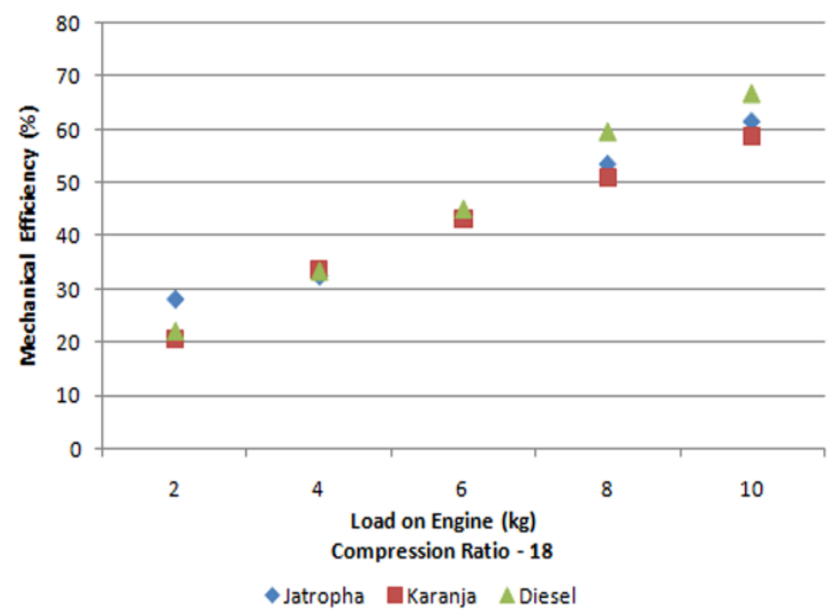

Figure 17. Effect on Mechanical Efficiency CR-18.

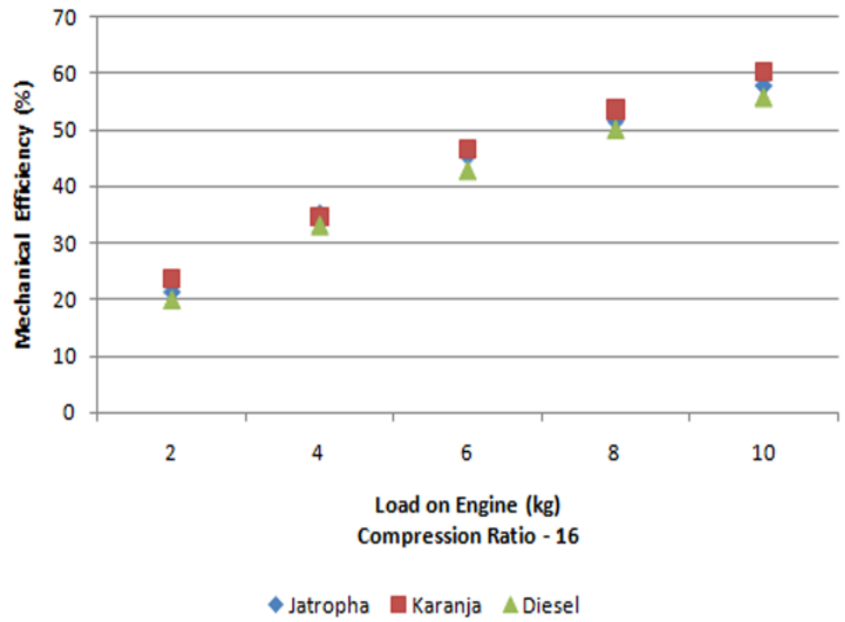

Figure 18. Effect on Mechanical Efficiency CR-16.

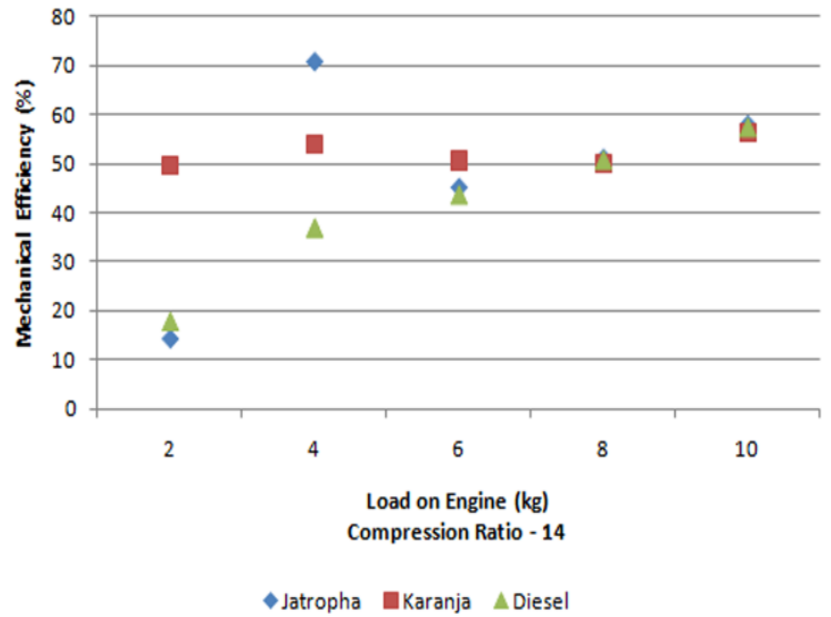

Figure 19. Effect on Mechanical Efficiency CR-14.

Karanja fuel at a load range of 6 to $10 \mathrm{~kg}$. For a CR 16 Jatropha fuel has an efficiency 2.5 to $3.8 \%$ lower than that of Karanja fuel. For a CR 14 Jatropha has slightly higher efficiency compared with Karanja fuel. This indicates that the Jatropha fuel can have a better performance at CR 16 .

\subsubsection{Volumetric Efficiency}

It was observed that (Figures 20-22) at CR 18 and load range of 2 to $6 \mathrm{~kg}$, Diesel fuel has volumetric efficiency less than Jatropha and Karanja. However with increase in load Diesel fuel has better volumetric efficiency than Jatropha and Karanja fuel. At CR 16 Karanja fuel has better volumetric efficiency than diesel and Jatropha. 


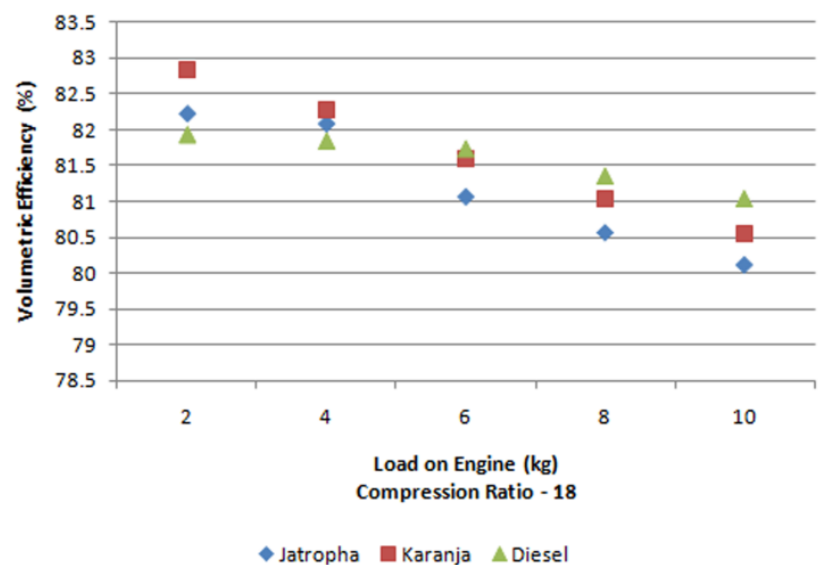

Figure 20. Effect on Volumetric Efficiency CR-18.

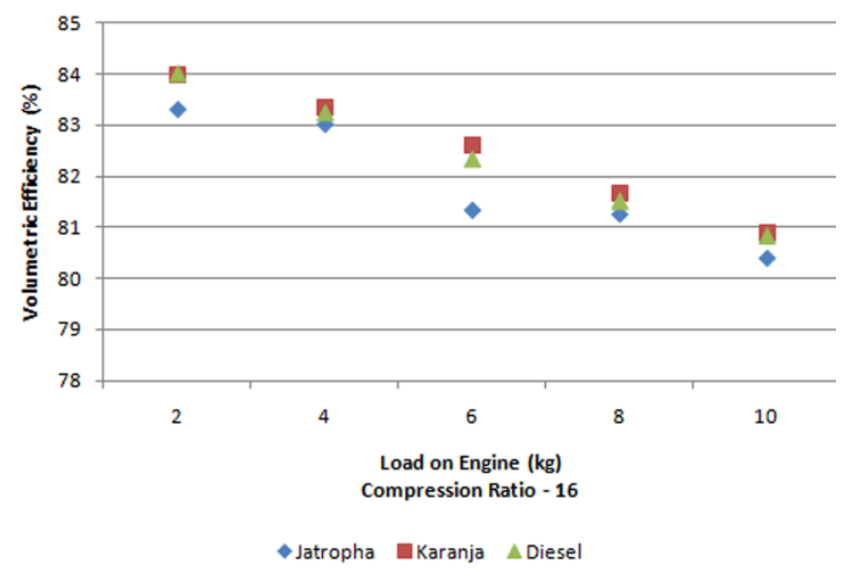

Figure 21. Effect on Volumetric Efficiency CR-16.

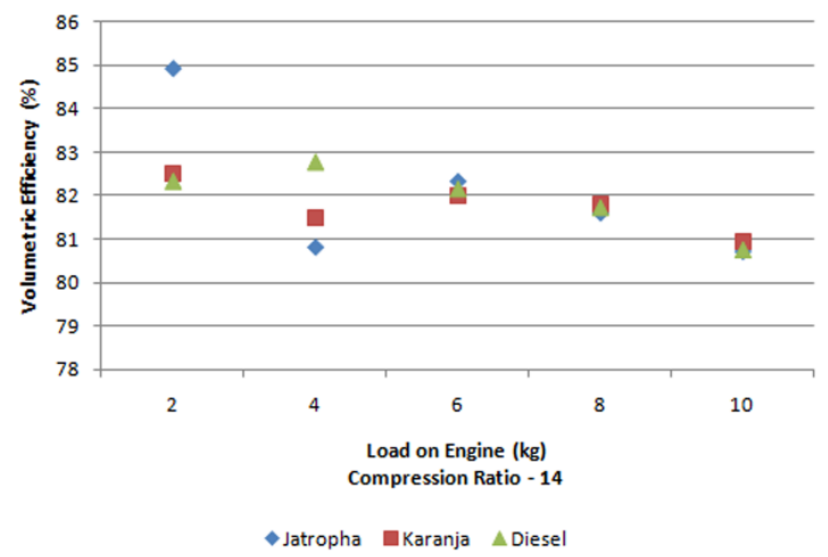

Figure 22. Effect on Volumetric Efficiency CR-14.

\subsection{Emission Analysis}

\subsubsection{Effect on CO Emission}

It is observed that CR has a significant impact on $\mathrm{CO}$ emissions (Figure 23-25). At CR 18 and at low load (2 kg) Karanja fuel has 50\% less emission compared with Diesel fuel and $42.85 \%$ less than Jatropha Biodiesel. With increasing load $\mathrm{CO}$ emission reduces. At $50 \%$ loading of the engine $(6 \mathrm{~kg})$ Karanja fuel has $0 \%$ CO emission where as for the Diesel fuel it is $0.001 \%$ and that of Jatropha is $0.004 \%$. With reduction in compression ratio CR 16 , at low load $(2 \mathrm{~kg})$ Karanja has $23.55 \%$ higher CO emission compared with Jatropha and $20.93 \%$ higher than Diesel. However with increase in load CO emission was reduced. At higher load $(10 \mathrm{~kg}$ ) Karanja has 50\% higher emissions than Jatropha. At CR 14 Jatropha has decreasing trend of $\mathrm{CO}$ emissions and about $75 \%$ reduction is observed. At

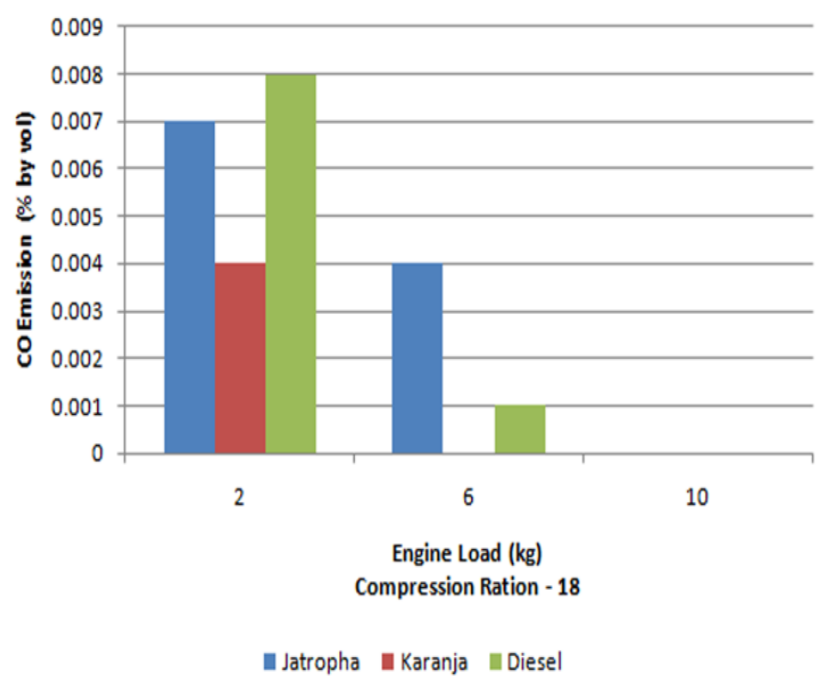

Figure 23. Effect on CO Emission CR-18.

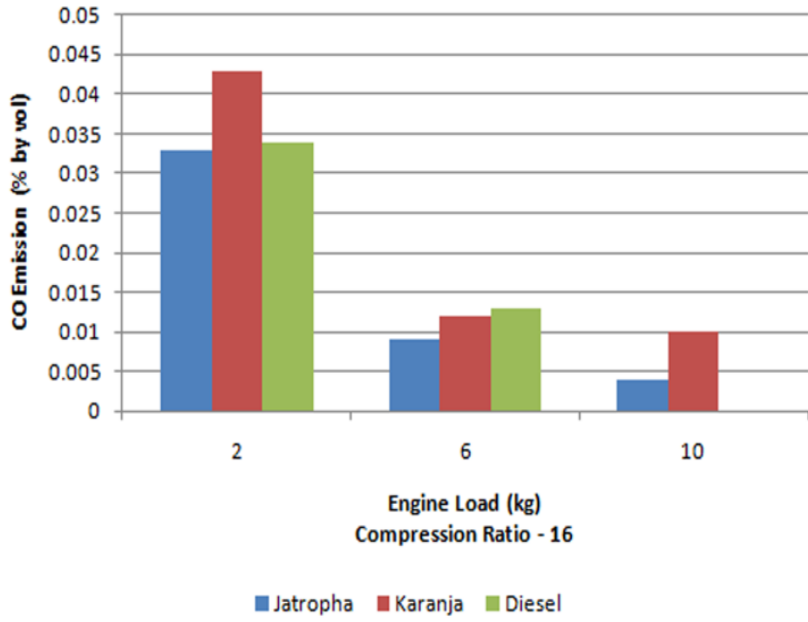

Figure 24. Effect on CO Emission CR-16.

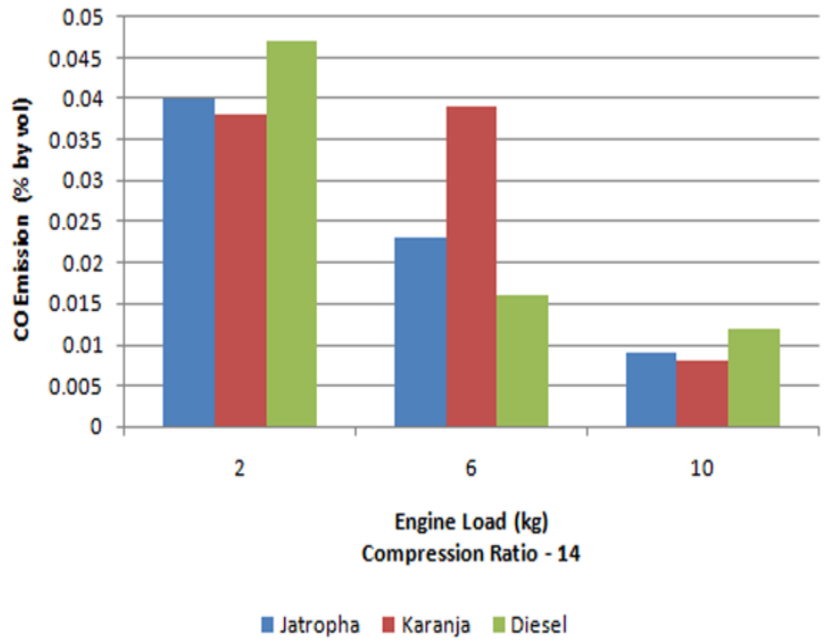

Figure 25. Effect on CO Emission CR-14.

higher load of $10 \mathrm{~kg}$ Jatropha and Karanja Biodiesel has $37.5 \%$ less emission than that of Diesel fuel. $\mathrm{CO}$ emission tends to reduce using biodiesel due to higher $\mathrm{O}_{2}$ content and lower carbon to hydrogen ratio in biodiesel compared with diesel. Some fluctuations are also observed this may be due to higher viscosity and poor spray characteristics of biodiesel. 


\subsubsection{Effect on $\mathrm{CO}_{2}$ Emission}

At compression ratio 18 and low load of $2 \mathrm{~kg}, \mathrm{CO}_{2}$ emission from Jatropha was observed to be $13.33 \%$ less than that of Diesel fuel and about $12 \%$ lower than Karanja. At higher load of $10 \mathrm{~kg}$ with increase in compression ratio $\mathrm{CO}_{2}$ concentration for Jatropha fuel is also increasing. About a $33.33 \% \mathrm{CO}_{2}$ emission increase was observed for Jatropha fuel as CR increases from 14 to 18 . This is an obvious fact due to the increase in combustion efficiency $\mathrm{CO}$ was reduced hence $\mathrm{CO}_{2}$ is increased. However, for Karanja fuel it is observed that at full load of $10 \mathrm{~kg}, \mathrm{CO}_{2}$ emission was increased by about $31.88 \%$ as compression ratio increases from 14 to 18 (Figures 26-28).

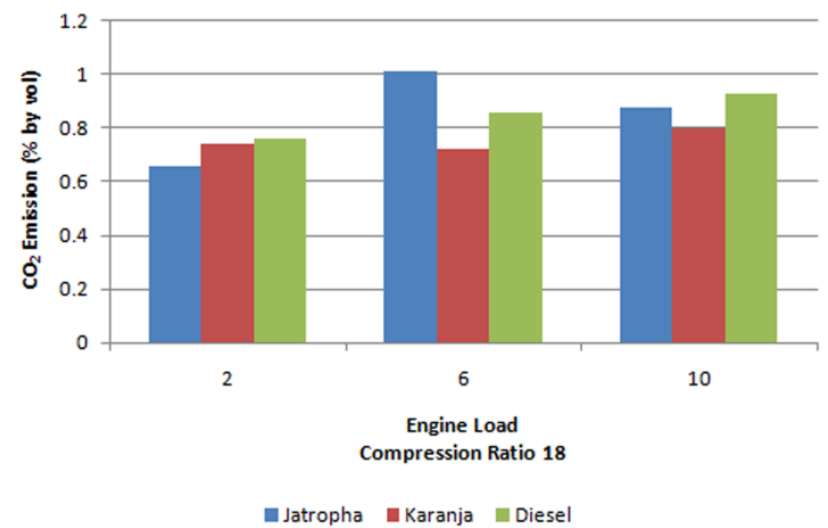

Figure 26. Effect on $\mathrm{CO}_{2}$ Emission CR-18.

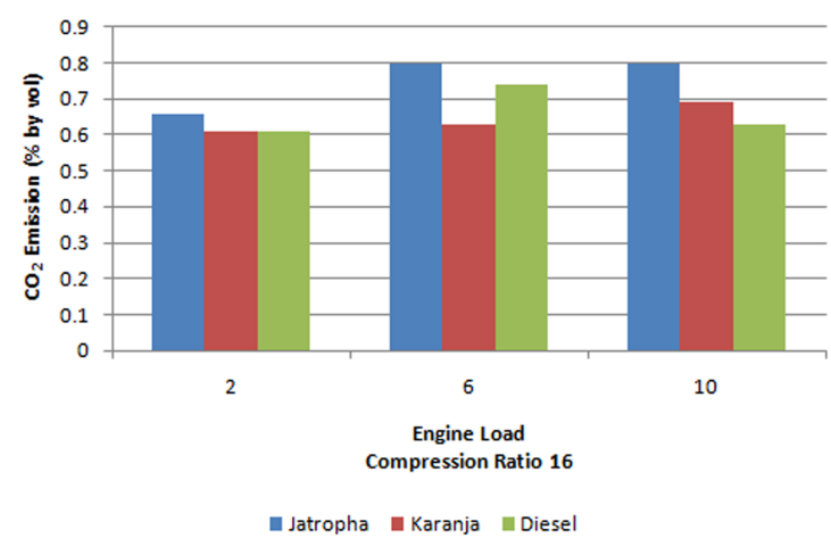

Figure 27. Effect on $\mathrm{CO}_{2}$ Emission CR-16.

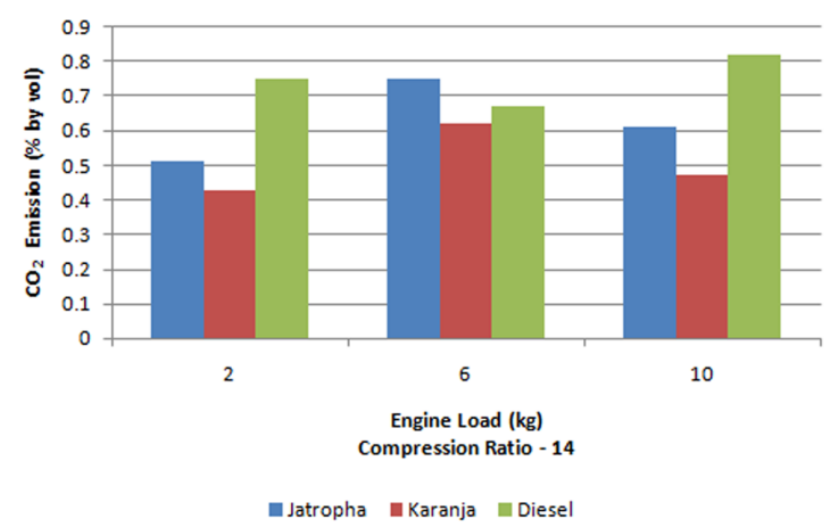

Figure 28. Effect on $\mathrm{CO}_{2}$ Emission CR-14.

\subsubsection{Effect on NOx Emission}

It is observed that the $\mathrm{NO}_{\mathrm{x}}$ emission increases for every fuel with increasing load on the engine (Figures 29-31) since increasing load on the engine increases the combustion temperature. For Karanja fuel $\mathrm{NO}_{\mathrm{x}}$ emission was low compared with Diesel and Jatropha. For Karanja fuel at full load $(10 \mathrm{~kg}) \mathrm{NO}_{\mathrm{x}}$ emission was lower by about

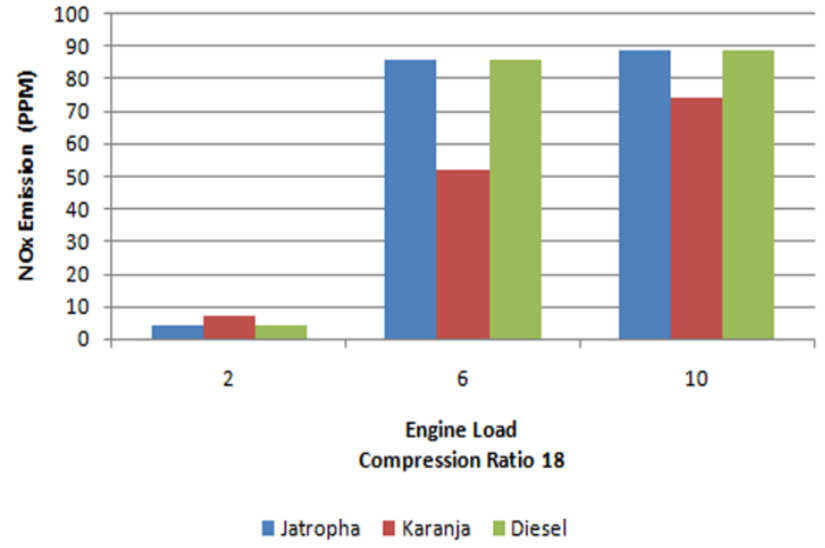

Figure 29. Effect on $\mathrm{NO}_{x}$ Emission CR-18.

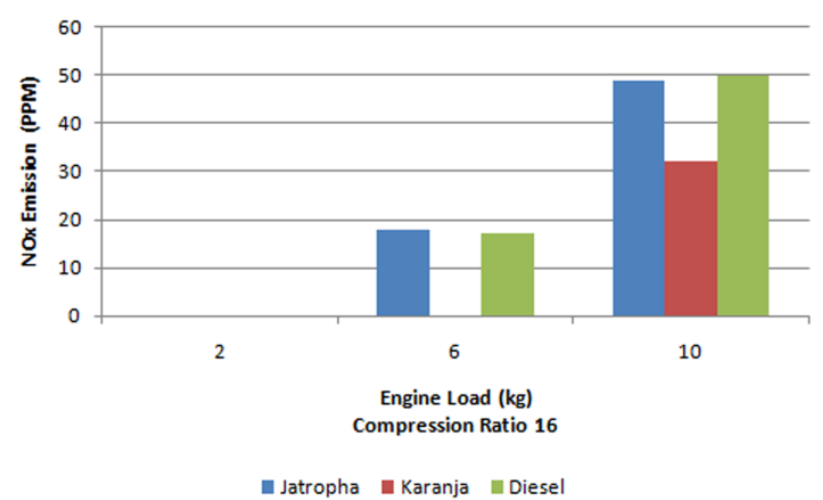

Figure 30. Effect on $\mathrm{NO}_{x}$ Emission CR-16.

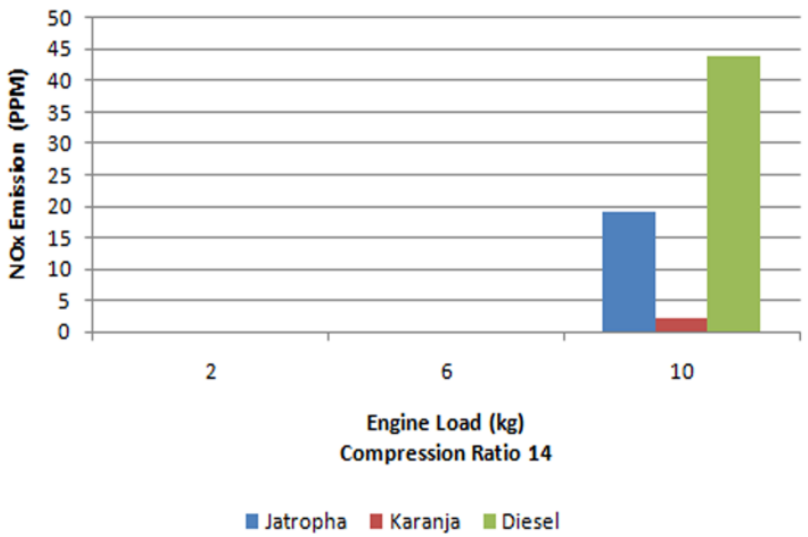

Figure 31. Effect on $\mathrm{NO}_{x}$ Emission CR-14.

$20 \%$ compared with Diesel and Jatropha. At part load operation $(6 \mathrm{~kg})$ and CR 18 Karanja fuel has $41.18 \%$ lower $\mathrm{NO}_{\mathrm{x}}$ emission than Jatropha and $25.37 \%$ lower $\mathrm{NO}_{\mathrm{x}}$ than Diesel fuel. $\mathrm{NO}_{\mathrm{x}}$ emission was observed to be significant in Diesel and Jatropha at a CR of 16. 36\%. $\mathrm{NO}_{\mathrm{x}}$ emission was higher for Diesel fuel and 34\% higher for Jatropha fuel compared with Karanja. At CR 14 Karanja fuel is having 93.18\% lower $\mathrm{NO}_{\mathrm{x}}$ emission than Diesel and $83.33 \%$ less than Jatropha. Jatropha fuel is having $59.1 \%$ less $\mathrm{NO}_{\mathrm{x}}$ emission compared with Diesel fuel. The higher cetane number of a biodiesel makes it to burn early and hence soften the pressure and hence the temperature. This may be the reason that the Karanja is having lower $\mathrm{NO}_{\mathrm{x}}$ emission than other fuels.

\subsubsection{Effect on HC Emission}

It is observed that at CR 18 Diesel fuel is having higher $\mathrm{HC}$ emission than any other fuel. At full load of $10 \mathrm{~kg}$ Diesel fuel has $60 \%$ higher emission compared with Karanja and Jatropha fuel. It is observed that Jatropha and 


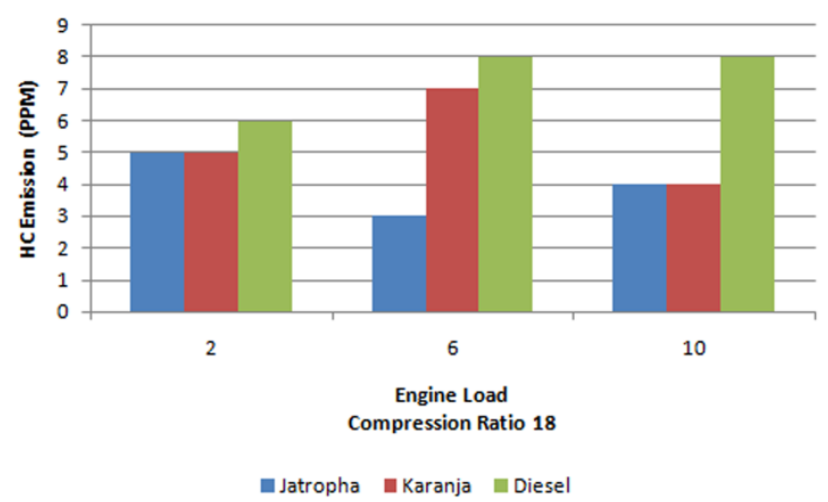

Figure 32. Effect on HC Emission CR-18.

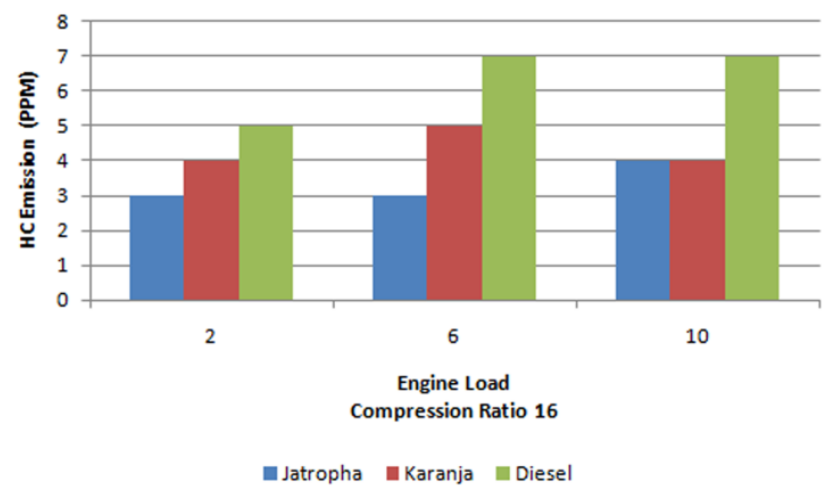

Figure 33. Effect on HC Emission CR-16.

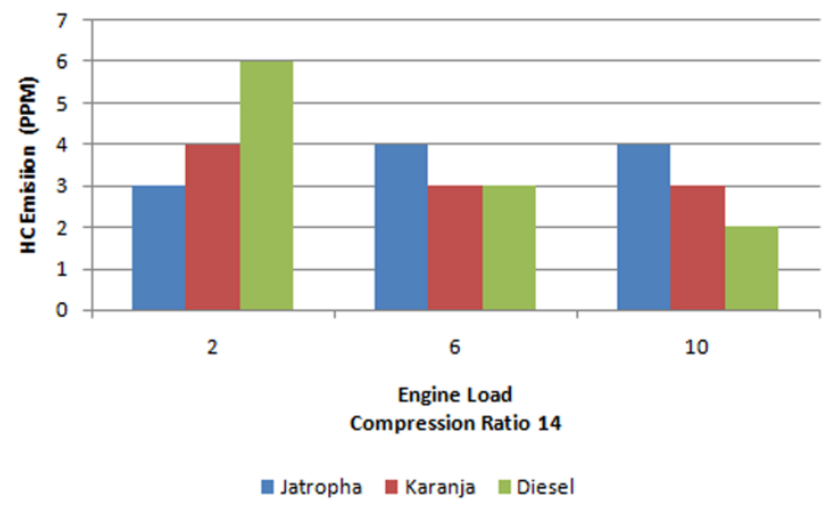

Figure 34. Effect on HC Emission CR-14.

Karanja are having almost same $\mathrm{HC}$ emission. At a low CR $14 \mathrm{HC}$ emission is observed to be small compared with CR 18 (Figures 32-34).

\subsection{Effect of Load and CR}

Figure 35 shows the effect of load and CR on SFC of an engine for Diesel Fuel. It is observed that with increase in load on engine SFC decreases. About $40 \%$ decrease in SFC is observed when the load on the engine increases from 0 to $40 \%$ of rated power. As CR increases from 14 to 16 , SFC decreased by about $10 \%$ however it decreases by about $22 \%$ as CR increases from 16 to 18 . Figures 36 and 37 represents effects on SFC of Karanja and Diesel Fuel. SFC of Karanja fuel was observed to be higher than diesel fuel. This is because of the high density of biodiesel.

Figures 38, 39 and 40 represent the effect of load and $\mathrm{CR}$ on brake thermal efficiency (BTE) of an engine. It is observed that with increase in CR from 14 to 16 , for diesel fuel a slight decrease in BTE of engine is observed however it again increases as CR increases to 18. For Karanja and Jatropha biodiesel BTE increases linearly with increase in CR from 14 to 18. At full load BTE is same for all the

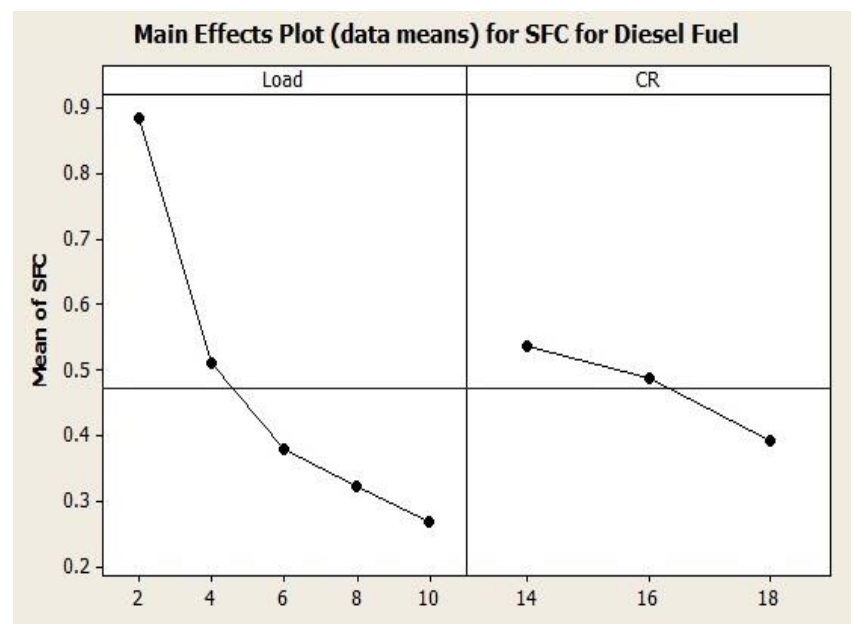

Figure 35. Effect of Load and CR on SFC-Diesel Fuel.

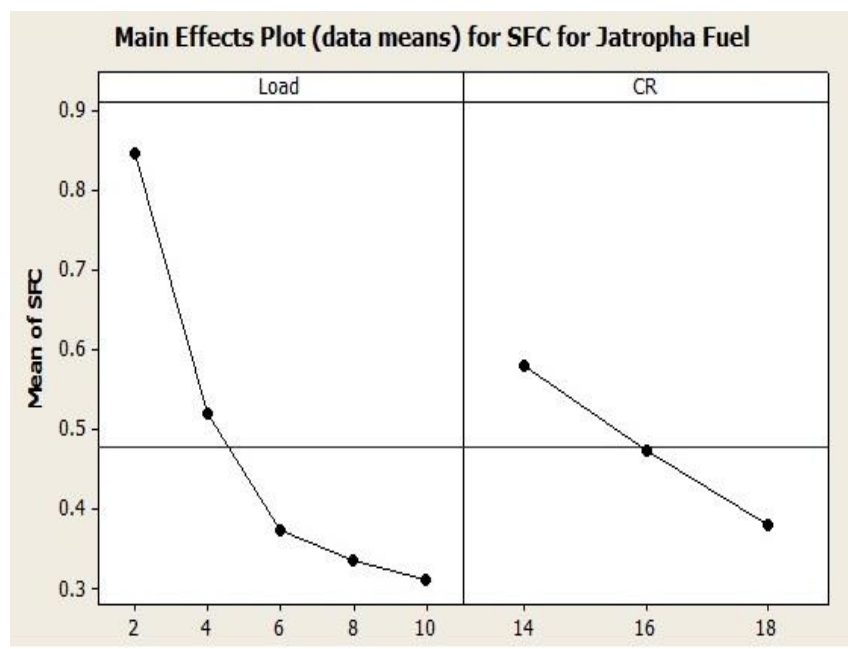

Figure 36. Effect of Load and CR on SFC-Jatropha Fuel.

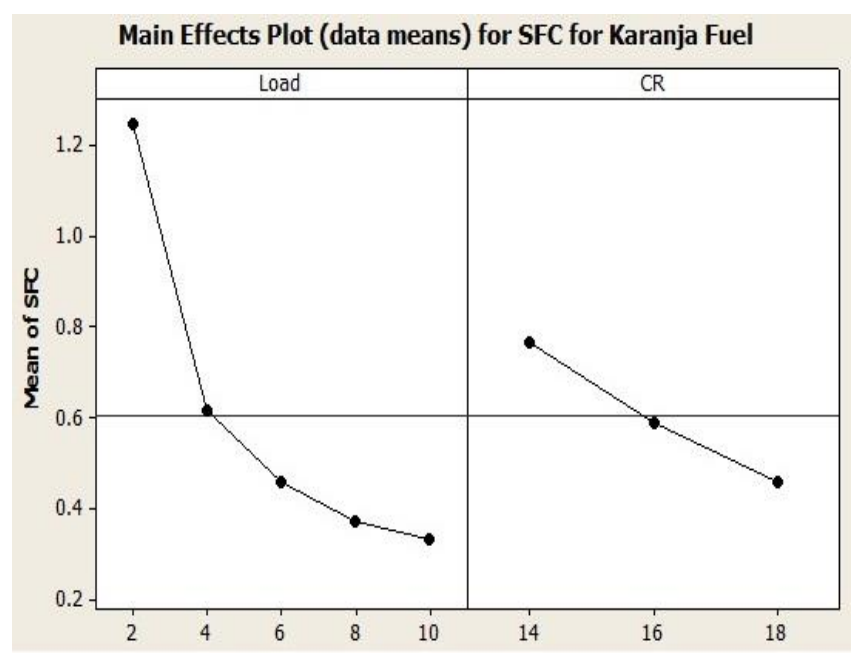

Figure 37. Effect of Load and CR on SFC - Karanja Fuel.

fuels. This is because of loss of heating value of biodiesel and increase in fuel consumption.

Figures 41, 42 and 43 represent effect of load and CR on $\mathrm{CO}$ emission of an engine. It is observed that increase in load and CR decreases the CO emission. Higher decrease is available when load increases up to $60 \%$ of rated power. This is mainly due to complete combustion. With increase in CR turbulence increases which causes complete combustion. It is observed that the $\mathrm{CO}$ emission of 
biodiesel was lower than diesel fuel, and this is because of excess oxygen present in the biodiesel.

Figures 44, 45 and 46 represent effect of load and CR on $\mathrm{NO}_{\mathrm{x}}$ emission of engine. For diesel engine it is observed that the $\mathrm{NO}_{\mathrm{x}}$ emission increases with increase in load and $\mathrm{CR}$. This is because of increase in temperature during the combustion. $\mathrm{NO}_{\mathrm{x}}$ of biodiesel fuel is low. This is because of high cetane number that burns the biodiesel early which softens the pressure and temperature.

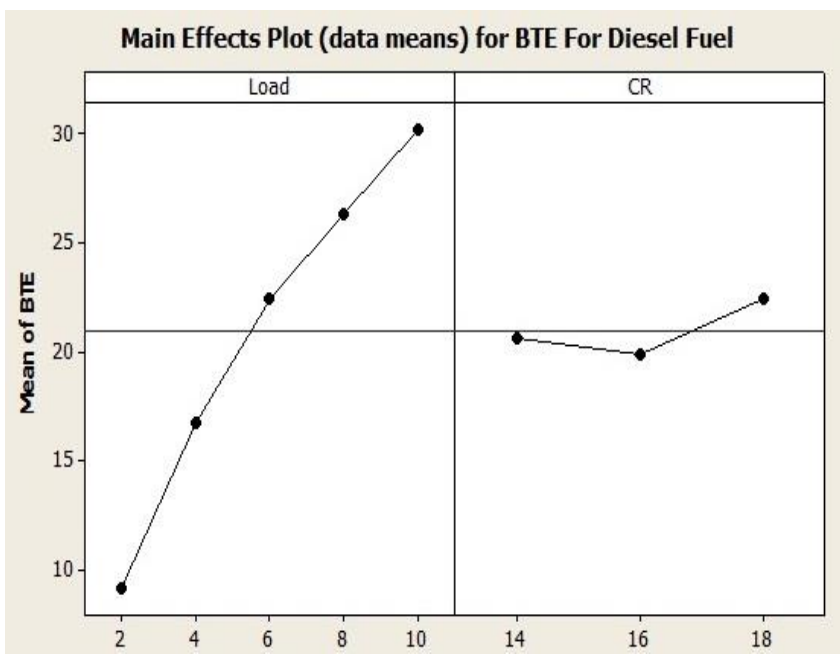

Figure 38. Effect of Load and CR on BTE - Diesel Fuel.

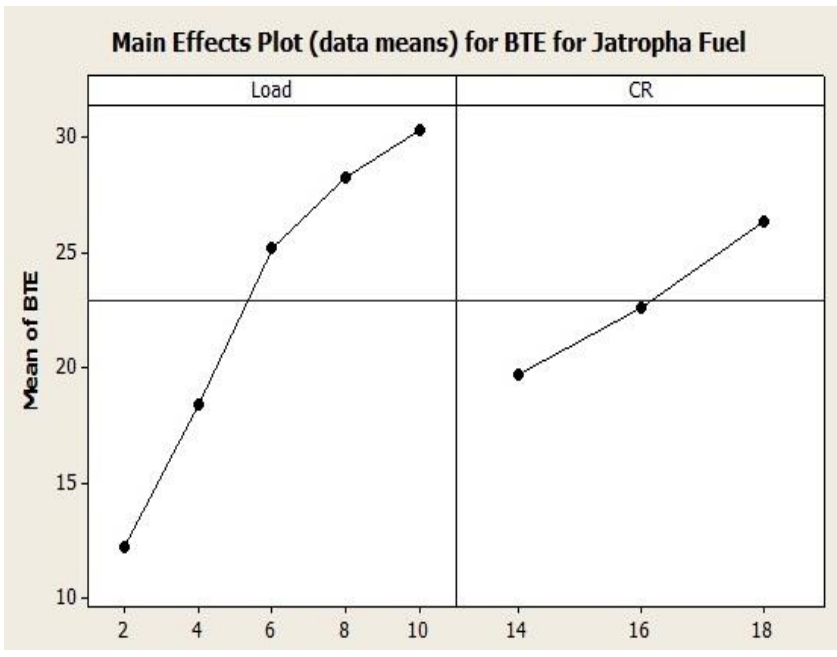

Figure 39. Effect of Load and CR on BTE-Jatropha Fuel.

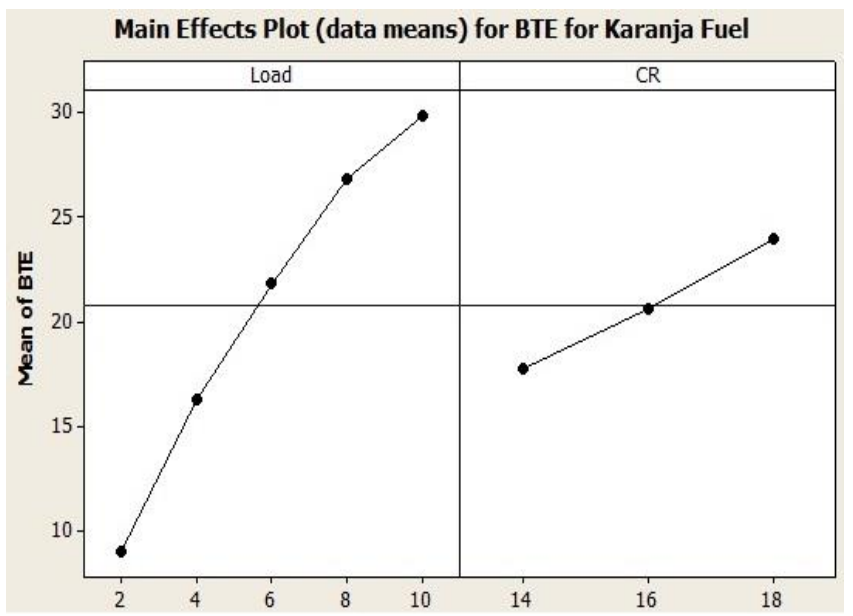

Figure 40. Effect of Load and CR on BTE-KaranjaFuel.

\subsection{Conclusion}

1. For Jatropha fuel it is observed that the peak pressure was higher than Karanja fuel at any compression ratio. Longer delay results in higher pressure. At CR 18 for Karanja fuel $47 \%$ higher pressure rise were observed than Jatropha fuel. However at low compression ratio 16 and 14 this pressure is more or less same. Blending of two fuels may result in better performance at low compression ratio.

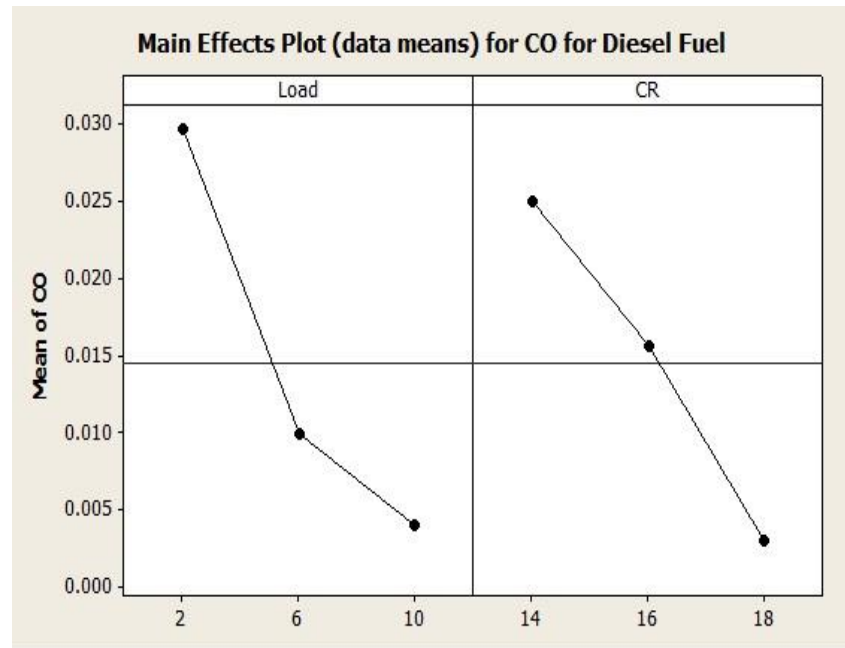

Figure 41. Effect of Load and CR on CO emission - Diesel Fuel.

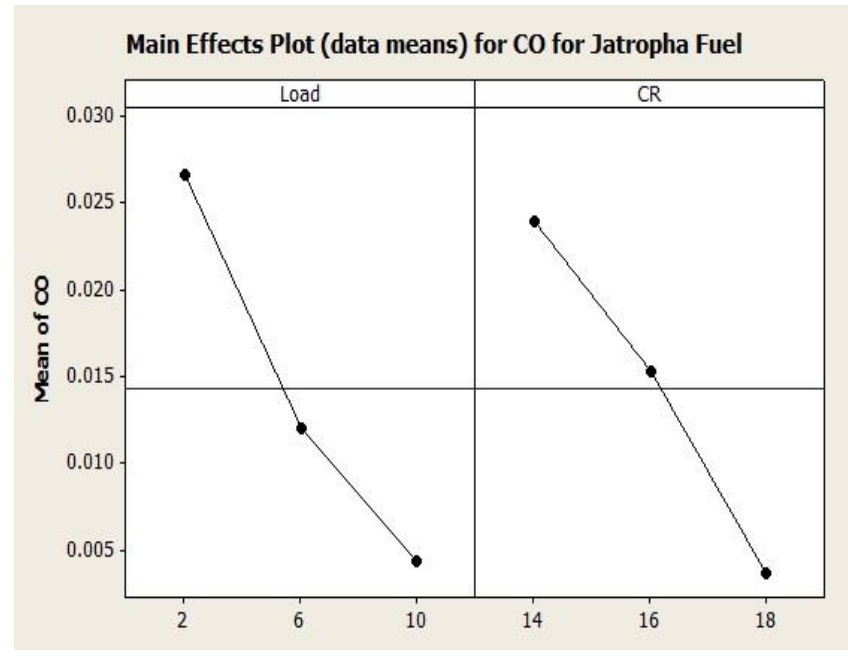

Figure 42. Effect of Load and CR on CO emission Jatropha Fuel.

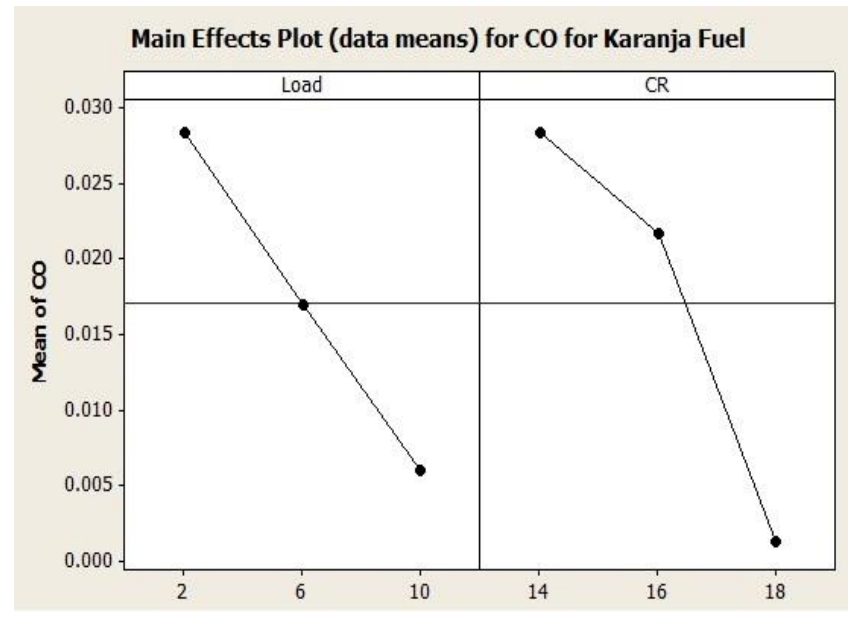

Figure 43. Effect of Load and CR on CO emission Karanja Fuel. 


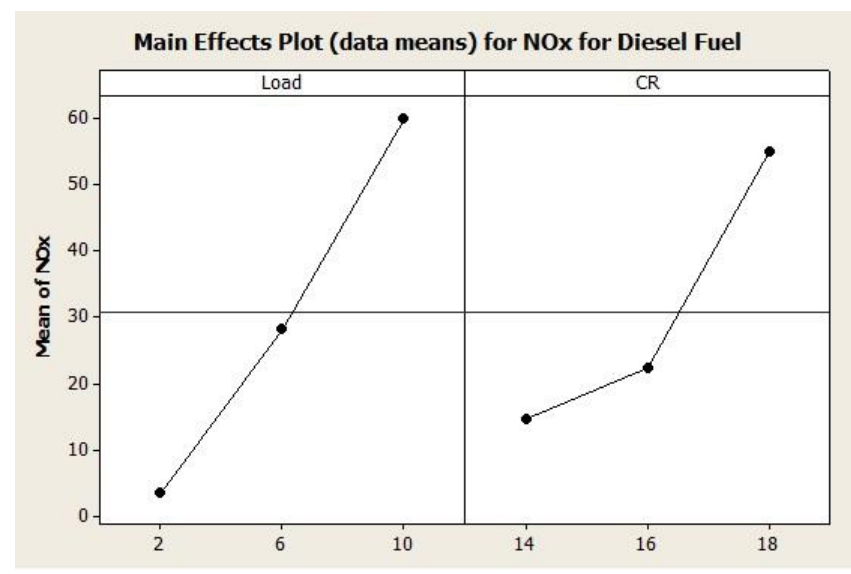

Figure 44. Effect of Load and CR on NOx emission - Diesel Fuel.

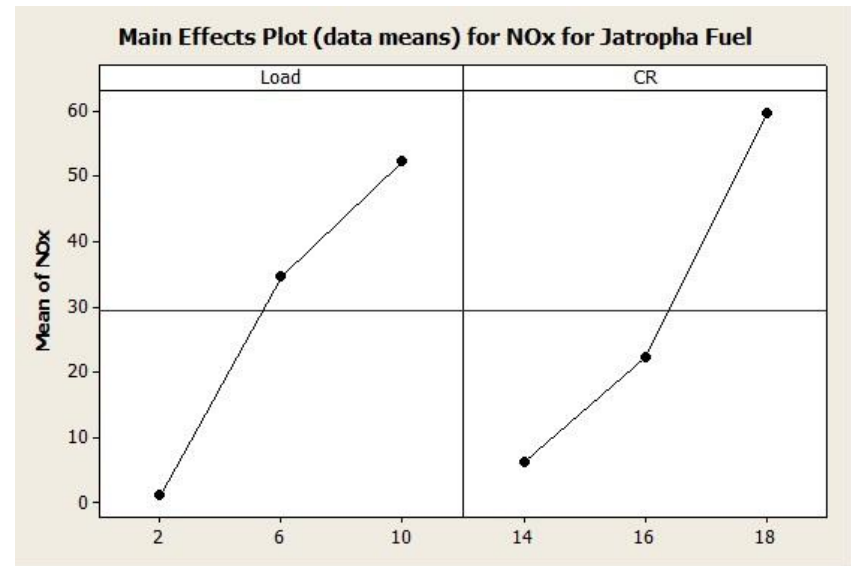

Figure 45. Effect of Load and CR on NOx emission Jatropha Fuel.

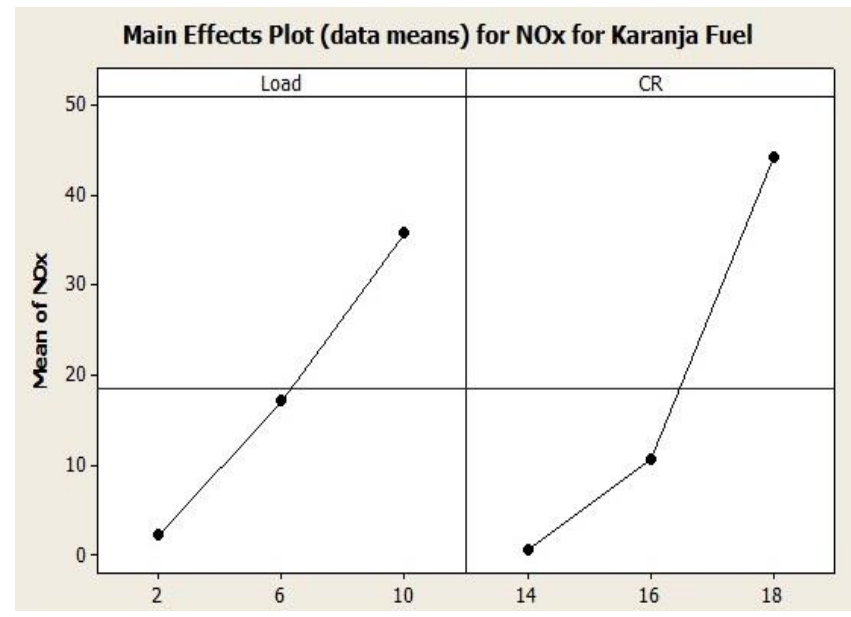

Figure 46. Effect of Load and CR on NOx emission Karanja Fuel.

2. It is observed that for Jatropha fuel $50 \%$ of the mass was burned at about 12 degree after TDC and for Karanja it is at about 3 degree after TDC. This indicates a longer delay period for Jatropha biodiesel compared to Karanja biodiesel.

3. No significant effects were observed for break power for any fuel.

4. It was observed that at low loads of 2 to $6 \mathrm{~kg}$ Karanja fuel consumption is about 11 to $30 \%$ higher compared with
Jatropha biodiesel. This is mainly due to higher density and viscosity. It was observed that for Karanja biodiesel SFC is higher at any compression ratio compared with Diesel and Jatropha Biodiesel. Loss of heating value for Karanja biodiesel is $15 \%$ which is more compared with Jatropha biodiesel. For three CR's 18, 16 and 14 it is observed that the SFC decreases with increase in load and at a maximum load of $10 \mathrm{~kg}$ about $10 \%$ higher fuel consumption was observed. At low load for Karanja biodiesel SFC is very much higher compared with Diesel fuel at low load of $2 \mathrm{~kg}$ and about $20 \%$ higher fuel consumption is observed. Fuel consumption is higher obviously because of loss of heating value and higher density than that of diesel fuel. This indicates that blending of more than two biodiesels OR blending of biodiesels with the diesels may result in some advantages with respect to diesel fuel.

5. At CR 16 mechanical efficiency of Jatropha fuel is 3 to $5 \%$ more than that of diesel and for Karanja fuel it is 4 to $8 \%$ more than that of diesel fuel for the entire range of loads ( $2 \mathrm{~kg}$ to $10 \mathrm{~kg}$ ). However, at CR 14 Jatropha fuel has efficiency similar to Diesel fuel and observed to be higher at low load. For Karanja fuel efficiency is about 13 to $30 \%$ higher at low load compared with diesel for load range of 2 to $6 \mathrm{~kg}$. For CR 18 Jatropha fuel has efficiency 1 to $4.5 \%$ more than Karanja fuel at a load range of 6 to $10 \mathrm{~kg}$. For a CR 16 Jatropha fuel has efficiency 2.5 to $3.8 \%$ lower than that of Karanja fuel. Thus fuel with multi-blend $(\mathrm{J}+\mathrm{K}+\mathrm{D})$ with varying combinations and at fixed compression ratio can be verified for better performance.

6. $\mathrm{CO}$ emission tends to be reduced using biodiesel due to higher $\mathrm{O}_{2}$ content and lower carbon to hydrogen ratio in biodiesel compared with diesel. Performance may be evaluated for multi-blend fuel.

7. At part load operation $(6 \mathrm{~kg})$ and CR 18 Karanja fuel has $41.18 \%$ lower $\mathrm{NO}_{\mathrm{x}}$ emission than Jatropha and $25.37 \%$ $\mathrm{NO}_{\mathrm{x}}$ lower than Diesel fuel. $\mathrm{NO}_{\mathrm{x}}$ emission was observed to be significant in Diesel and Jatropha at a CR 16. $\mathrm{NO}_{\mathrm{x}}$ emission was 36\% higher for Diesel fuel and 34\% higher for Jatropha fuel compared to Karanja. At CR 14 Karanja fuel is has $93.18 \%$ lower $\mathrm{NO}_{\mathrm{x}}$ emission than Diesel and $83.33 \%$ less than Jatropha. Jatropha fuel has $59.1 \%$ less $\mathrm{NO}_{\mathrm{x}}$ emission compared with Diesel fuel. The higher cetane number of a biodiesel makes it to burn early and hence softens the pressure and hence the temperature. This may be the reason that the Karanja is having lower $\mathrm{NO}_{\mathrm{x}}$ emission than other fuel. Thus blends of Jatropha and Karanja may results in to lower NOx emission.

\section{Acknowledgements:}

The authors are very much thankful to S. S. V. P. S's Bapusaheb Shivajirao Deore College of Engineering, Dhule for providing their valued support and availability of Research lab for this experimental work. More over continuous technical support from Prof. Milind S. Patil is highly appreciated.

\begin{tabular}{ll}
\multicolumn{2}{l}{ Nomenclatures } \\
$B D C$ & Bottom Dead Centre \\
$B S F C$ & Break Specific Fuel Consumption \\
$B T$ & Break Thermal \\
$C A$ & Crank Angle \\
$C O$ & Carbon Monoxide Emission \\
$C \mathrm{O}_{2}$ & Carbon dioxide Emission \\
$C R$ & Compression Ratio
\end{tabular}




$\begin{array}{ll}C V & \text { Heating Value of Fuel }\left(\mathrm{kJ} . \mathrm{kg}^{-1}\right) \\ D & \text { Diesel Fuel } \\ H C & \text { Hydrocarbon Emission } \\ \mathrm{K} & \text { Karanja Fuel } \\ M G T & \text { Mean Gas Temperature } \\ N o x & \text { Oxides of Nitrogen Emission } \\ P & \text { Cylinder Pressure } \\ P M & \text { Particulate Matter } \\ S F C & \text { Specific Fuel Consumption } \\ T D C & \text { Top Dead Centre } \\ V C R & \text { Variable Compression Ratio } \\ \rho & \left.\text { Density of a Fuel (kg.m }{ }^{-3}\right) \\ & \\ \text { Greek Symbols } \\ \eta_{B T} & \text { Efficiency Brake Thermal } \\ \eta_{v o l} & \text { Efficiency Volumetric } \\ \eta_{M E C H} & \text { Efficiency Mechanical } \\ \theta & \text { Crank Angle }\end{array}$

\section{References:}

Al-Widyan, M., Tashtoush G., Abu-Qudais M. (2002). Utilization of Ethyl Ester of Waste Vegetable Oils as Fuel in Diesel Engines. Fuel Process Technology, 76, 91-103. doi: 10.1016/S0378-3820(02)00009-7.

Armas, O., Yehliu, K., Boehman, A. (2009). Effect of Alternative Fuels on Exhaust Emissions during Diesel Engine Operation with Matched Combustion Phasing. Fuel, 89, 438-456. doi: 10.1016/j.fuel.2009.09.022.

Aydin, H., Bayindir, H. (2010). Performance and Emission Analysis of Cottonseed Oil Methyl Ester in a Diesel Engine. Renewable Energy, 35, 588-592. doi: 10.1016/j.renene.2009.08.009.

Buyukkaya, E. (2010). Effects of Biodiesel on a DI Diesel Engine Performance, Emission and Combustion Characteristics, Fuel, 89, 3099-3105. doi: 10.1016/j.fuel.2010.05.034.

Carraretto, C., Macor, A., Mirandola, A., Stoppato, A., Tonon, S. (2004). Biodiesel as Alternative Fuel: Experimental Analysis and Energetic Evaluations. Energy, 29, 2195-2211. doi: 10.1016/j.energy.2004.02.042

Choi, S. H., Oh, Y. (2006).The Emission Effects by the Use of Biodiesel Fuel, Int J Mod Phy B, 20, 4481-4486. doi: 10.1142/S0217979206041550.

Da Silva Fernando, N., Antonio, S., Jorge R. (2003). Technical Feasibility Assessment of Oleic Sunflower Methyl Ester Utilization in Diesel Bus Engines, Energy Conversion Management, 44, 2857-2878.

Ghobadian, B., Rahimi, H., Nikbakht, A. M., Najafi G., Yusaf, T. F. (2009). Diesel Engine Performance and Exhaust Emission Analysis using Waste Cooking Biodiesel Fuel with an Artificial Neural Network, Renewable Energy, 34, 976-82. 10.1016/j.renene.2008.08.008.

Godiganur S., Murthy C. H. S., Reddy, R. P. (2010). Performance and Emission Characteristics of a Kirloskar HA394 Diesel Engine Operated on Fish Oil Methyl Esters, Renewable Energy, 35, 355-359. DOI: 10.1016/j.renene.2009.07.007.
Gumus, M., Kasifoglu, S. (2010). Performance and Emission Evaluation of a Compression Ignition Engine using a Biodiesel (Apricot Seed Kernel Oil Methyl Ester) and Its Blends with Diesel Fuel. Biomass and Bioenergy, 34, 134-139. doi: 10.1016/j.biombioe.2009.10.010.

Hansen, A., Gratton, M., Yuan, W. (2006). Diesel Engine Performance and Nox Emissions From Oxygenated BioFuels And Blends With Diesel Fuel. Trans ASABE, 49, 589-95.

Hasimoglua, C., Ciniviz, M., Ozsert, I., Icingur, Y., Parlak, A., Salman, M. C. (2008). Performance Characteristics of a Low Heat Rejection Diesel Engine Operating with Biodiesel, Renewable Energy, 33, 1709-1715.

Karabektas, M. (2009). The Effects of Turbocharger on the Performance and Exhaust Emissions of a Diesel Engine Fuelled With Biodiesel. Renewable Energy, 34, 989993. doi: 10.1016/j.renene.2008.08.010.

Lepori, W., Engler, C., Johnson, L. A., Yarbrough, C. M., (1992). Animal Fats As Alternative Diesel Fuels in Liquid Fuels from Renewable Resources. AEC, Proceedings of an Alternative Energy Conference. American Society of Agricultural Engineers, Nasheville, TN, 89-98.

Lin, B. F., Huang, J. H., Huang, D. Y. (2009). Experimental Study of the Effects of Vegetable Oil Methyl Ester on DI Diesel Engine Performance Characteristics and Pollutant Emissions, Fuel, 88, 1779-85. doi: 10.1016/j.fuel.2009.04.006.

Lujan, J. M., Bermudez, V., Tormos, B., Pla, B. (2009). Comparative Analysis of a DI Diesel Engine Fuelled with Biodiesel Blends during the European MVEG-A Cycle: Performance and emissions (II), Biomass Bioenergy, 33, 948-56. doi: 10.1016/j.biombioe.2009.02.003.

Mahanta, P., Mishra, S. C., Kushwah, Y. S. (2006). An Experimental Study of Pongamia Pinnata L. Oil as a Diesel Substitute, $P$ I Mechanical Engineering A-J PW, 220, 803-8.

Masjuki, H. S. (1993). Biofuel as Diesel Fuel Alternative: An Overview. J. Energy Heat Mass Transfer, 15, 293304.

Monyem, A., Van Gerpen, J., Canakci, M. (2001). The Effect of Timing and Oxidation on Emissions from Biodiesel-Fueled Engines, Trans ASAE, 44, 35-42.

Oner, C., Altun, S. (2009). Biodiesel Production From Inedible Animal Tallow And An Experimental Investigation Of Its Use As Alternative Fuel In A Direct Injection Diesel Engine, Applied Energy, 86, 21142120 .

Ozsezen AN, Canakci M, Turkcan A, Sayin C. (2009). Performance and Combustion Characteristics of a DI Diesel Engine Fuelled with Waste Palm Oil and Canola Oil Methyl Esters. Fuel, 88, 629-636.

Raheman, H., Phadatare, A. G. (2004). Diesel Engine Emissions and Performance from Blends of Karanja Methyl Ester and Diesel. Biomass Bioenergy, 27, 393-7. doi: 10.1016/j.biombioe.2004.03.002. 
Reyes, J. F, Sepulveda, M. (2006). PM-10 Emissions and Power of a Diesel Engine Fueled with Crude and Refined Biodiesel from Salmon Oil. Fuel, 85, 17141719.

Sahoo, P. K., Das L. M., Babu, M. K. G., Arora P., Singh V. P, Kumar N. R. (2009). Comparative Evaluation of Performance and Emission Characteristics of Jatropha, Karanja and Polanga Based Biodiesel as Fuel in a Tractor Engine. Fuel, 88, 1698-707.

doi: 10.1016/j.fuel.2009.02.015.

Song, J. T, Zhang, C. H. (2008). An Experimental Study on the Performance and Exhaust Emissions of a Diesel
Engine Fuelled With Soybean Oil Methyl Ester. $P$ I Mechanical Engineering, D-J Aut, 222, 2487-96. doi: 10.1243/09544070JAUTO932.

Stavarache, C., Vinatoru, M., Nishimura, R, Maed, Y. (2005). Fatty Acids Methyl Esters from Vegetable Oil by Means of Ultrasonic Energy.UltrasonSonochem, 12, 367-72. doi: 10.1016/j.ultsonch.2004.04.001.

Ulusoy, Y., Tekin, Y. C., Etinkaya, M., Kapaosmanoglu, F. (2004). The Engine Tests of Biodiesel from Used Frying Oil. Energy Source Part A 26, 927-32. doi: 10.1080/00908310490473219. 